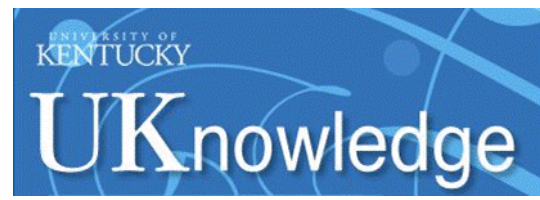

University of Kentucky

UKnowledge

10-10-2021

\title{
Fischer-Tropsch Synthesis: Effect of the Promoter's Ionic Charge and Valence Level Energy on Activity
}

\author{
Mirtha Z. Leguizamón León Ribeiro \\ Universidad Nacional de Asunción, Paraguay \\ Joice C. Souza \\ Universidade Federal Fluminense, Brazil \\ Muthu Kumaran Gnanamani \\ University of Kentucky, muthu.gnanamani@uky.edu \\ Michela Martinelli \\ University of Kentucky, michela.martinelli@uky.edu \\ Gabriel F. Upton \\ University of Texas at San Antonio
}

See next page for additional authors

Follow this and additional works at: https://uknowledge.uky.edu/caer_facpub

Part of the Chemical Engineering Commons, and the Mechanical Engineering Commons

Right click to open a feedback form in a new tab to let us know how this document benefits you.

\section{Repository Citation}

Leguizamón León Ribeiro, Mirtha Z.; Souza, Joice C.; Gnanamani, Muthu Kumaran; Martinelli, Michela; Upton, Gabriel F.; Jacobs, Gary; and Ribeiro, Mauro C., "Fischer-Tropsch Synthesis: Effect of the Promoter's Ionic Charge and Valence Level Energy on Activity" (2021). Center for Applied Energy Research Faculty and Staff Publications. 41.

https://uknowledge.uky.edu/caer_facpub/41

This Article is brought to you for free and open access by the Center for Applied Energy Research at UKnowledge. It has been accepted for inclusion in Center for Applied Energy Research Faculty and Staff Publications by an authorized administrator of UKnowledge. For more information, please contact UKnowledge@lsv.uky.edu. 
Fischer-Tropsch Synthesis: Effect of the Promoter's Ionic Charge and Valence Level Energy on Activity

\section{Digital Object Identifier (DOI)}

https://doi.org/10.3390/reactions2040026

\section{Notes/Citation Information}

Published in Reactions, v. 2, issue 4.

(c) 2021 by the authors. Licensee MDPI, Basel, Switzerland.

This article is an open access article distributed under the terms and conditions of the Creative Commons Attribution (CC BY) license (https://creativecommons.org/licenses/by/4.0/).

\section{Authors}

Mirtha Z. Leguizamón León Ribeiro, Joice C. Souza, Muthu Kumaran Gnanamani, Michela Martinelli, Gabriel F. Upton, Gary Jacobs, and Mauro C. Ribeiro 


\title{
Article \\ Fischer-Tropsch Synthesis: Effect of the Promoter's Ionic Charge and Valence Level Energy on Activity
}

\author{
Mirtha Z. Leguizamón León Ribeiro ${ }^{1}$, Joice C. Souza ${ }^{2}$, Muthu Kumaran Gnanamani ${ }^{3}$, Michela Martinelli ${ }^{3}$, \\ Gabriel F. Upton ${ }^{4}$, , Gary Jacobs ${ }^{4,5}$ and Mauro C. Ribeiro ${ }^{2, *}$ (D) \\ 1 Laboratório de Análisis Molecular y Elemental, Facultad de Ciencias Exactas y Naturales, FACEN/UNA, \\ San Lorenzo 2160, Paraguay; mirthaleguizamon@facen.una.py \\ 2 Departamento de Química, Universidade Federal Fluminense, Des. Ellis Hermydio Figueira 483, \\ Volta Redonda, Rio de Janeiro 27213-145, Brazil; joice_souza@id.uff.br \\ 3 University of Kentucky Center for Applied Energy Research, 2540 Research Park Drive, \\ Lexington, KY 40511, USA; muthu.gnanamani@uky.edu (M.K.G.); michela.martinelli@uky.edu (M.M.) \\ 4 Department of Biomedical Engineering and Chemical Engineering, UTSA, One UTSA Circle, \\ San Antonio, TX 78249, USA; gabeupton@ymail.com (G.F.U.); gary.jacobs@utsa.edu (G.J.) \\ 5 Department of Mechanical Engineering, UTSA, One UTSA Circle, San Antonio, TX 78249, USA \\ * Correspondence: mauroribeiro@id.uff.br; Tel.: +55-24-98111-9333
}

Citation: Ribeiro, M.Z.L.L.; Souza, J.C.; Gnanamani, M.K.; Martinelli, M.; Upton, G.F.; Jacobs, G.; Ribeiro, M.C. Fischer-Tropsch Synthesis: Effect of the Promoter's Ionic Charge and Valence Level Energy on Activity. Reactions 2021, 2, 408-426. https:// doi.org/10.3390/reactions2040026

Academic Editor: József Sándor Pap

Received: 21 August 2021

Accepted: 5 October 2021

Published: 10 October 2021

Publisher's Note: MDPI stays neutral with regard to jurisdictional claims in published maps and institutional affiliations.

Copyright: (c) 2021 by the authors. Licensee MDPI, Basel, Switzerland. This article is an open access article distributed under the terms and conditions of the Creative Commons Attribution (CC BY) license (https:// creativecommons.org/licenses/by/ $4.0 /)$.
Abstract: In this contribution, we examine the effect of the promoter's ionic charge and valence orbital energy on the catalytic activity of Fe-based catalysts, based on in situ synchrotron X-ray powder diffraction (SXRPD), temperature-programmed-based techniques (TPR, TPD, CO-TP carburization), and Fischer-Tropsch synthesis catalytic testing studies. We compared the promoting effects of $\mathrm{K}$ (a known promoter for longer-chained products) with $\mathrm{Ba}$, which has a similar ionic radius but has double the ionic charge. Despite being partially "buried" in a crystalline $\mathrm{BaCO}_{3}$ phase, the carburization of the Ba-promoted catalyst was more effective than that of $\mathrm{K}$; this was primarily due to its higher (2+) ionic charge. With $\mathrm{Ba}^{2+}$, higher selectivity to methane and lighter products were obtained compared to the K-promoted catalysts; this is likely due to Ba's lesser capability of suppressing $\mathrm{H}$ adsorption on the catalyst surface. An explanation is provided in terms of a more limited mixing between electron-filled $\mathrm{Ba}^{2+} 5 \mathrm{p}$ and partially filled $\mathrm{Fe} 3 \mathrm{~d}$ orbitals, which are expected to be important for the chemical promotion, as they are further apart in energy compared to the $\mathrm{K}^{+}$ $3 p$ and Fe $3 d$ orbitals.

Keywords: Fischer-Tropsch synthesis; iron; alkali; ion valance; alkali-earth; promoter

\section{Introduction}

Iron-based catalysts are an interesting choice for Fischer-Tropsch synthesis (FTS), where $\mathrm{CO}$ is hydrogenated to a mixture of hydrocarbons that can be upgraded and used as transportation fuels, lubricants, waxes, and other value-added products [1]. Part of the suitability of iron-based catalysts for FTS stems from their relatively lower cost (vis à vis cobalt-based catalysts). Furthermore, a residual Fe oxide phase that is present in the active catalyst enhances $\mathrm{H}_{2}$ production via its intrinsic water-gas shift (WGS) activity, thus enabling the use of $\mathrm{H}_{2}$ depleted, coal-derived syngas as a feed. Structural promoters, such as $\mathrm{Al}, \mathrm{Mg}$, and $\mathrm{Si}$, positively impact catalyst performance by minimizing both the crystallite sintering and filter-clogging mechanical disintegration of the catalyst during working conditions [2]. Chemical promoters, such as alkalis and $\mathrm{Cu}$, increase the coverage of the active phase [3]. Furthermore, small amounts of potassium may also enhance both activity and selectivity, mainly toward more value-added, longer-chained products $[1,4]$. Many efforts [1,3-5] have been dedicated to investigating the nature of the effect of potassium, which has been observed to increase the carburization rate during catalyst activation [5], resulting in the formation of a mixture of metastable iron carbides that seem to coexist in a dynamic equilibrium on the catalyst surface under FTS conditions. These carbides 
may be classified by the geometry of the interstices in the iron lattice that carbon may occupy. There are the octahedral carbides (OC), where carbon occupies somewhat distorted octahedral interstices. The so-called $\varepsilon$ carbides $\left(\varepsilon-\mathrm{Fe}_{3} \mathrm{C}\right.$ and $\left.\eta-\mathrm{Fe}_{2} \mathrm{C}\right)$ belong to this $\mathrm{OC}$ carbide type. Likewise, there are carbides where carbon occupies trigonal prismatic (TP) interstices. $\chi-\mathrm{Fe}_{5} \mathrm{C}_{2}$ (the Hägg carbide), $\theta-\mathrm{Fe}_{3} \mathrm{C}$ (cementite), and $\mathrm{Fe}_{7} \mathrm{C}_{3}$ (Eckström-Hadcock carbide) fall within this TP category. Hägg carbide $\left(\chi-\mathrm{Fe}_{5} \mathrm{C}_{2}\right)$ has been proposed by some researchers to provide the most active carbidic phase for FTS [6] and is actually known to be the main phase under such conditions [7], along with $\eta-\mathrm{Fe}_{2} \mathrm{C}$ and $\varepsilon-\mathrm{Fe}_{3} \mathrm{C}[8,9] . \theta-\mathrm{Fe}_{3} \mathrm{C}$ is usually formed at temperatures above $310^{\circ} \mathrm{C}$ and is the most thermodynamically stable product of the Fe-C carbon system and is less active than the Hagg carbide [10]. The carbide discovered by Eckström and Hadcock $\left(\mathrm{Fe}_{7} \mathrm{C}_{3}\right)$ [11] has also been shown to form specifically in $\mathrm{SiO}_{2}$-promoted catalysts $[12,13]$ under realistic FTS conditions. Nevertheless, knowledge about the carbidic structure that comprises the active phase for FTS in an iron-based catalyst is still a matter of intense debate, as there are many metastable carbidic phases that are relatively close in energy and therefore may be present in transient concentrations in the catalyst over the FTS temperature range $\left(250-350^{\circ} \mathrm{C}\right)$ [14], as shown in Figure 1.

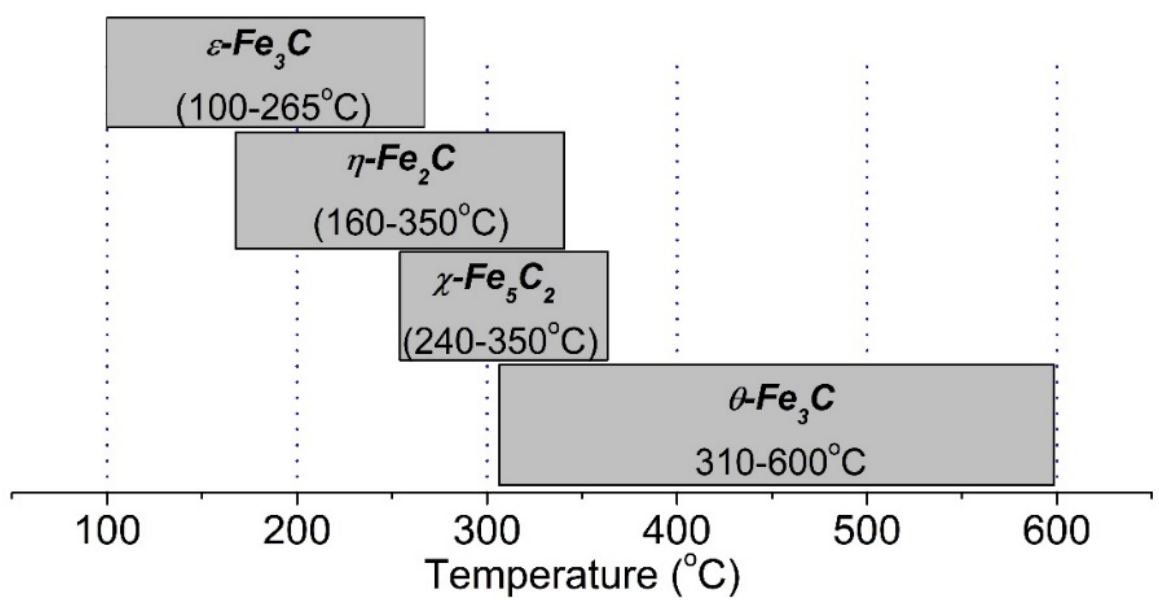

Figure 1. Expected temperature ranges for the several iron carbides, based on [14].

It should be expected that a particular phase distribution would be highly dependent on the experimental conditions and might rearrange after activation once exposed to the FTS feed [14-16]. In this regard, there is evidence that the nature of the promoter and particle size distribution also seem to play a role in determining the iron carbide phase distribution [12], which likely affects the temperature limits shown in Figure 1. Thus, research into the possible effect of the promoter (e.g., alkali) on active catalyst phase composition is ongoing.

Potassium enhances CO dissociative adsorption while inhibiting $\mathrm{H}$ adsorption $[17,18]$, and the explanation for this has been given in terms of an electronically inductive effect that the $\mathrm{K}^{+}$ion may exert on its vicinity either directly or via the oxygen bridges that it has with the catalyst surface $[19,20]$, as it is expected that $\mathrm{K}$ is in a +1 formal oxidation state (e.g., present as a hydroxide, carbonate, formate, oxide, etc.). Such an electronic effect may be rationalized in terms of its large ionic radius (152 pm) due to the $3 \mathrm{p}^{6} 4 \mathrm{~s}^{0}$ valence levels compared to its charge. On the other hand, it should be expected that the alkali is likely present in the active catalyst in the form of a nanocrystalline phase whose nature is not entirely known. It may involve some sub-nanocrystalline carbonate (or related) phase [20,21], although it is also probable that this phase involves the formation of a K/Fe mixed oxide surface phase [22]. Some researchers have discussed the effect of K compared to other Group I alkali elements, attempting to ascertain the effect of the alkali size and the uniqueness of $\mathrm{K}$ as a good promoter in Fe-based FTS catalysts [5,23-26]. From these studies, a general, long-known $[27,28]$ correlation between the production of longer-chained products and alkali basicity (which is directly related to alkali ion radius) 
emerges. However, this observation is complicated by the effect of the alkalis on other parallel reaction pathways, such as the catalyst deactivation caused by excessive carbon formation, or the WGS, which may influence activity/selectivity simply due to differences in the $\mathrm{H}_{2}$ supply locally occurring inside the reactor. Regarding the formerly mentioned deactivation issue, it is expected that basic alkali promoters (e.g., $\mathrm{Rb}, \mathrm{Cs}$ ) that are too large would lead to carburization that is too rapid, resulting in carbon buildup on the catalyst surface $[5,23,26]$ and alkali carbonates that are too stable at FTS temperatures $[20,21,29]$. On the other hand, light alkali elements ( $\mathrm{Li}, \mathrm{Na}$ ) are expected to result in lower syngas conversions due to their lower WGS activities, which would limit FTS in coal-derived, low $\mathrm{H}_{2}$ /CO ratio syngas feeds, which would also be due to their lower capacity to reduce iron oxides toward FTS active iron carbide phases [26].

Besides the above-mentioned considerations of the effect of $\mathrm{K}^{+}$on iron catalyst surface chemistry, which should be mainly based on the electronic inductive effect the heavy alkali should exert on its vicinity, it might also be expected that the catalyst's surface acid-base chemistry should also be affected by the presence of the alkali. The acid-base chemistry change imparted by the presence of the alkali directly impacts the (transient) surface compounds that may be formed between the promoter ion and the FeOx matrix as well as with the adsorbed species (carbonates, formates, acetates, etc.). Considering these acid-base interactions merely in terms of ionic interactions, it might then be expected that the ionic charge of the promoter should play an important role, as it is known that the ionic lattice energies depend on the ionic charge. In this regard, in the present contribution, we aimed to investigate the effect of the promoter's ionic valence by comparing the effect of $\mathrm{K}^{+}$ with a $2+$ charged alkaline earth metal ion. In order to keep a suitable comparative basis, we then chose to compare it with $\mathrm{Ba}^{2+}$, as its ionic radius (149 pm) is quite comparable to that of $\mathrm{K}^{+}(152 \mathrm{pm})$, being only around $2 \%$ smaller than its alkaline counterpart. Moreover, $\mathrm{Ba}^{2+}$ has a $n p^{6}(\mathrm{n}+1) \mathrm{s}^{0}$ valence level that is quite similar to that of $\mathrm{K}^{+}\left(\mathrm{Ba}^{2+}: 5 \mathrm{p}^{6} 6 \mathrm{~s}^{0}\right.$ vis à vis $\mathrm{K}^{+}$: $\left.3 \mathrm{p}^{6} 4 \mathrm{~s}^{0}\right)$, which might $a$ priori normalize any possible crystal field effects, even though they have different valence energies. In fact, alkaline-earth elements have also been considered to be promoters in iron-based catalysts in a few studies [30-36], although only a minor promoting effect has been observed. In the present contribution, we investigate the effect of the ionic charge and valence level of the promoter on the carburization rate, activity, selectivity, and stability of Fe-based catalysts. This is the first study on this subject as far as we are aware. To this end, iron-based catalysts with the atomic formula $5 \mathrm{Me}$ : $100 \mathrm{Fe}$ $(\mathrm{Me}=\mathrm{K}$ or $\mathrm{Ba})$ were prepared and characterized by synchrotron X-ray powder diffraction (SXRPD), temperature-programmed-based techniques (TPR, TPD, CO-TP carburization), and FTS catalytic testing.

\section{Materials and Methods}

\subsection{Catalyst Preparation}

Fe-based catalysts were prepared by the precipitation of a $0.1 \mathrm{M} \mathrm{Fe}\left(\mathrm{NO}_{3}\right)_{3} \cdot 9 \mathrm{H}_{2} \mathrm{O}$ (Aldrich, St. Louis, MO, USA, 99\%) solution with concentrated ammonia solution (Dinamica, (Indaiatuba, São Paulo, Brazil), 28-30\%) to reach a nominal Fe: $\mathrm{NH}_{3}$ molar ratio of 1:10. The suspension was then stirred for over $30 \mathrm{~min}$ at room temperature and was then vacuum-filtered. After the filtration of the precipitated cake and drying at $120^{\circ} \mathrm{C}$ for $10 \mathrm{~h}$, it was calcined in a muffle furnace at $400{ }^{\circ} \mathrm{C}$ over the course of $10 \mathrm{~h}$ under stagnant ambient air. This iron oxide support was then impregnated to the point of incipient wetness $(0.3 \mathrm{~mL}$ of solution per gram of support) with $\mathrm{K}_{2} \mathrm{CO}_{3}$ (Vetec, (Rio de Janeiro, Rio de Janeiro, Brazil)), 99\%) and $\mathrm{Ba}\left(\mathrm{NO}_{3}\right)_{2}$ (Vetec, (Rio de Janeiro, Rio de Janeiro, Brazil), 99\%)) solutions. The $\mathrm{K}_{2} \mathrm{CO}_{3}$ solution was treated with a few drops of $0.01 \mathrm{M}$ dilute $\mathrm{HNO}_{3}$ (Synth (Diadema, São Paulo, Brazil), 37\% solution) solution prior to the impregnation until total gas elimination in order to minimize the presence of carbonates in the dried catalyst precursor. After impregnation, the precursors were then dried at $120{ }^{\circ} \mathrm{C}$ for $10 \mathrm{~h}$ under flowing air. The catalysts were prepared in order to attain a $5 \mathrm{Me}: 100 \mathrm{Fe}$ atomic ratio $(\mathrm{Me}=\mathrm{K}$, Ba). Distilled water was used in all of these procedures. 


\subsection{BET Surface Area and Porosity Measurements}

In order to study pore structure and surface specific area, Brunauer-Emmet-Teller (BET) experiments were performed in a Micromeritics 3-Flex system. The samples were pretreated upon temperature ramping to $160^{\circ} \mathrm{C}$ followed by evacuation at that temperature over the course of $12 \mathrm{~h}$ at $\sim 50 \mathrm{mTorr}$. Pore structure (pore volume, average pore diameter and pore size distribution) was determined using Barrett-Joyner-Hallenda (BJH) pore size and volume analysis.

\subsection{In Situ Synchrotron X-ray Diffraction}

The evolution of the crystalline phases in the catalysts while being exposed to $\mathrm{CO}$ and $\mathrm{CO}+\mathrm{H}_{2}$ mixtures (at 1 bar) was studied by in situ synchrotron X-ray diffraction (SXRPD) at the X-ray powder diffraction beamline (XPD) located in the Brazilian Synchrotron Light Source (LNLS-Campinas). The samples were placed into a rotating sample holder located inside a furnace (Canário) that allowed gas flowing during the analysis. The samples were then irradiated with $7000 \mathrm{eV}(\lambda=1.7712 \AA)$ light in a Hübner $4+2$ circle diffractometer. Heat treatment of the samples, as depicted in Figure 2, occurred in three steps: (i) temperature ramping $\left(2{ }^{\circ} \mathrm{C} \mathrm{min}-1\right)$ up to $270{ }^{\circ} \mathrm{C}$ followed by a (ii) $1 \mathrm{~h}$ soaking at $270{ }^{\circ} \mathrm{C}$ under $100 \mathrm{~mL}$ $\min ^{-1} 5 \% \mathrm{CO}(\mathrm{He})$ (White Martins (Campinas, São Paulo, Brazil)) and (iii) $1 \mathrm{~h}$ flowing in $85 \mathrm{~mL} \mathrm{~min}^{-1}$ of mixture containing $2.5 \% \mathrm{CO}$ and $1.75 \% \mathrm{H}_{2}$ diluted in $\mathrm{He}$ (1:0.7 $\mathrm{CO}$ to $\mathrm{H}_{2}$ molar ratio) (White Martins (Campinas, São Paulo, Brazil)), while the temperature was kept at $270{ }^{\circ} \mathrm{C}$. This mixture was made using $50 \mathrm{~mL} \mathrm{~min}^{-1}$ of $5 \% \mathrm{CO}(\mathrm{He})$ (White Martins (Campinas, São Paulo, Brazil)) and $35 \mathrm{~mL} \mathrm{~min}^{-1}$ of a mixture with $5 \% \mathrm{H}_{2}(\mathrm{He})$ (White Martins (Campinas, São Paulo, Brazil)). Crystalline parameters (phase speciation, unit cell dimensions, atomic positions) were obtained via Rietveld analysis of the X-ray patterns using GSAS-II software [37]. The instrumental parameters were extracted using a NIST 676- $\mathrm{Al}_{2} \mathrm{O}_{3}$ standard XRD pattern that was retrieved under the same experimental setup considered in this work.

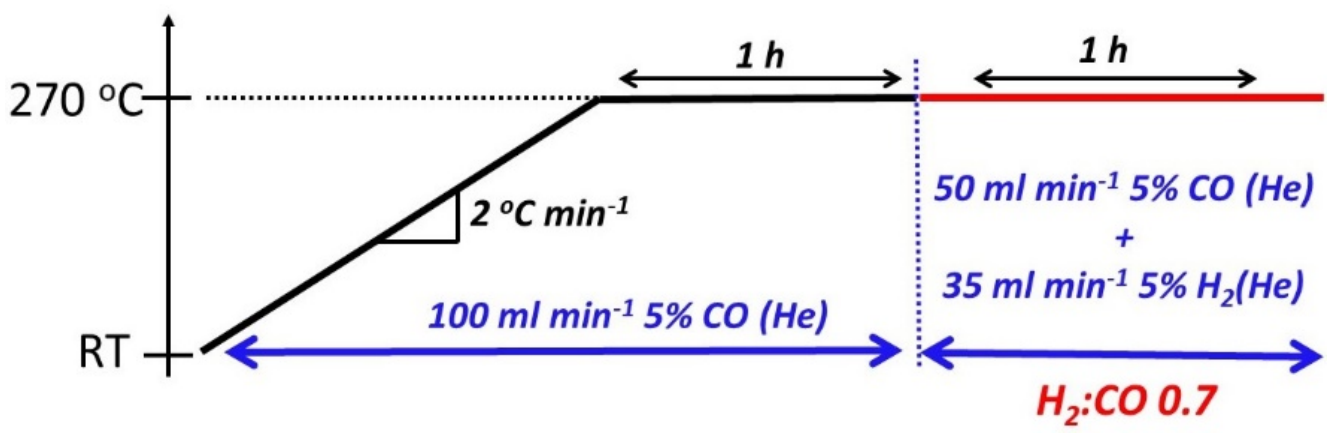

Figure 2. Temperature program used in the SXRD study.

\subsection{Temperature Programmed Reduction (TPR)}

$\mathrm{H}_{2}$ TPR profiles were recorded using an Altamira AMI-300R (Pittsburgh, PA, USA) unit equipped with a thermal conductivity detector (TCD). Catalysts $(33 \mathrm{mg})$ were first pretreated in flowing helium at $30 \mathrm{~mL} \mathrm{~min}^{-1}$ at $300{ }^{\circ} \mathrm{C}\left(1{ }^{\circ} \mathrm{C} \mathrm{min}-1\right.$ heating rate $)$ for $1 \mathrm{~h}$ and were cooled. TPR was performed using a $10 \% \mathrm{H}_{2}$ / Ar gas (Airgas, San Antonio, TX, USA) mixture referenced to argon (Airgas, San Antonio, TX, USA) at a flow rate of $30 \mathrm{~cm}^{3}$ $\mathrm{min}^{-1}$. Each sample was heated from 50 to $1000{ }^{\circ} \mathrm{C}$ using a heating ramp of $10^{\circ} \mathrm{C} \mathrm{min}^{-1}$.

\subsection{Hydrogen Temperature Programmed Desorption (TPD)}

Hydrogen TPD profiles were recorded using the Altamira AMI-300R (Pittsburgh, PA, USA) unit equipped with a TCD. In each experiment, catalysts $(400 \mathrm{mg})$ were activated in $\mathrm{H}_{2}\left(30 \mathrm{~mL} \mathrm{~min}^{-1}\right)$ (Airgas, San Antonio, TX, USA) by ramping $\left(1^{\circ} \mathrm{C} \mathrm{min}{ }^{-1}\right)$ to $400^{\circ} \mathrm{C}$ and holding for $1 \mathrm{~h}$. Catalysts were then cooled to $50{ }^{\circ} \mathrm{C}$ in flowing $\mathrm{H}_{2}$ and were held at 
that temperature for $1 \mathrm{~h}$. Argon (Airgas, San Antonio, TX, USA) was then flowed (30 mL $\mathrm{min}^{-1}$ ) as the temperature was increased to $800{ }^{\circ} \mathrm{C}$ at a ramp rate of $10{ }^{\circ} \mathrm{C} \mathrm{min}-1$.

\subsection{CO-Temperature Programmed Carburization/Mass Spectrometry (TPC-MS)}

Temperature programmed carburization mass spectrometry (TPC-MS) was performed using an Altamira AMI-300R catalyst characterization unit coupled to a Hiden quadrupole mass spectrometer (QMS). An amount of $4 \% \mathrm{CO} / \mathrm{He}$ (Airgas, San Antonio, TX, USA) was flowed at $25 \mathrm{~mL} \mathrm{~min}{ }^{-1}$ as the temperature was ramped at $10{ }^{\circ} \mathrm{C} / \mathrm{min}$ to $570{ }^{\circ} \mathrm{C}$ and was held for $50 \mathrm{~min}$. CO was analyzed using an online QMS (Hiden, Warrington, UK). Appropriate mass-to-charge ratios $(\mathrm{m} / \mathrm{z})$ that were examined were 28,16 , and 12 for $\mathrm{CO}$ and 44,28 , and 16 for $\mathrm{CO}_{2}$. Each experiment used $45 \mathrm{mg}$ of catalyst load.

\subsection{Catalytic Activity}

A continuously stirred-tank reactor (CSTR, Pressure products industries, PA, USA) made up of a stainless steel (316) autoclave $(1 \mathrm{~L})$ was used to perform the FTS reactions. The calibrated mass flow controllers from Brooks (5850 E series, Brooks Instruments, Halfield, PA, USA) were used to individually control the gas flow of $\mathrm{H}_{2}$ (UHP grade supplied by American Welding \& Gas, Lexington, KY, USA)), CO (UHP grade supplied by American Welding \& Gas, Lexington, KY, USA), and $\mathrm{N}_{2}$. (UHP grade supplied by Scott-Gross Company Inc., Lexington, KY, USA). The gas streams were delivered to the reactor via a dip tube. A Cr-Ni thermocouple was inserted into a thermowell that measures the reactor temperature in real time. Typically, $310 \mathrm{~g}$ of polywax-3000 (Baker Hughes, Houston, TX, USA), which acts as slurry medium, was placed into a 1 L CSTR and was heated to $140{ }^{\circ} \mathrm{C}$ so that the wax could melt at $140{ }^{\circ} \mathrm{C}$. About $8 \mathrm{~g}$ of iron catalyst was mixed with the polywax solvent. The FTS reactor was then purged with $\mathrm{CO}$ flow ( $24 \mathrm{slph})$ at the temperature and pressure of $270{ }^{\circ} \mathrm{C}$ and $1.2 \mathrm{MPa}$, respectively. This $\mathrm{CO}$ activation condition was maintained for $24 \mathrm{~h}$. After $\mathrm{CO}$ activation, the feed was switched from $\mathrm{CO}$ to syngas $\left(\mathrm{H}_{2}: \mathrm{CO}\right)$ at a mole ratio of $0.7: 1$ and a constant space velocity of syngas at $3.0 \mathrm{slph} / \mathrm{g}_{\text {cat }}$. The gas stream exiting the CSTR was subsequently passed through both warm and cold traps maintained to the temperatures of $100{ }^{\circ} \mathrm{C}$ and $0{ }^{\circ} \mathrm{C}$, respectively. A steady state was typically reached within $10 \mathrm{~h}$ after the beginning of the reaction. At this point, the effluent gases were sent to a dry test meter (DTM) followed by gas analysis being performed with an online micro-GC (Inficon, East Syracuse, NY, USA). The condensed products in the warm and cold traps were separated into oil and water phases. The oil phase was analyzed by an Agilent 7890 gas chromatograph (Agilent, Santa Clara, CA, USA) equipped with a DB-5 capillary column $(60 \mathrm{~m})$ and a flame ionization detector (FID). The aqueous part of the sample was analyzed using an SRI $8610 \mathrm{C}$ gas chromatograph (SRI Instruments, Earl St. Torrance, CA, USA) with a HayeSep Q packed column (9Ft 1/8 80/100 SS) and a TCD detector. Software developed at UK-CAER was used to process the gas analysis to determine conversion and selectivity based on Equations (1) and (2), given below:

$$
\begin{gathered}
\% C O_{\text {conv. }}=100 \cdot \frac{n_{C O, \text { in }}-n_{C O, \text { out }}}{n_{C O, \text { in }}} \\
\text { Selectivity }=100 \cdot \frac{n_{\text {product,out }} \cdot \text { carbon number }}{n_{C O, \text { in }}-n_{C O, o u t}}
\end{gathered}
$$

where $n_{\mathrm{CO}, \text { in }}$ and $n_{\mathrm{CO}, \text { out }}$ are the numbers of moles of $\mathrm{CO}$ fed and unconverted, respectively. $n_{\text {product,out }}$ is defined as the number of moles of a particular product being formed.

\section{Results}

\subsection{SXRPD Studies}

SXRPD patterns of the calcined catalyst precursors are displayed in Figure 3A. All the samples were initially comprised of $\alpha-\mathrm{Fe}_{2} \mathrm{O}_{3}$ (hematite), although the $\mathrm{K}$ - and Bacontaining samples also displayed additional small peaks, which can be observed within 
the $32^{\circ}$ to $55^{\circ} 2 \theta$ region, as shown in more detail in Figure 3B. In the K-promoted calcined precursor, peaks related to $\mathrm{FeCO}_{3}$ (ICSD 169791), $\mathrm{K}_{2} \mathrm{O}$ (ICSD 60489) and a Fe-K mixed oxide $\left(\mathrm{Fe}_{10.9} \mathrm{~K}_{1.55} \mathrm{O}_{17}\right.$ - ICSD 201095) were observed. The Ba-promoted calcined precursor displayed peaks related to $\mathrm{FeCO}_{3}$ (ICSD 169791), $\mathrm{BaCO}_{3}$ (ICSD 158379), and a Fe-Ba mixed oxide ( $\mathrm{BaFe}_{12} \mathrm{O}_{19}$ - ICSD 230509). These phases were likely formed during calcination and storage and tended to disappear with the carburization and reduction treatments that were performed. Figure $3 \mathrm{C}$ shows the patterns obtained after ramping the temperature to $270{ }^{\circ} \mathrm{C}$ and soaking at that temperature for $1 \mathrm{~h}$ under $5 \% \mathrm{CO}$ (balance $\mathrm{He}$ ). All the catalyst samples underwent phase changes such that diffraction lines related to magnetite could be observed in the three samples. Furthermore, diffraction lines related to other compounds, especially $\chi-\mathrm{Fe}_{5} \mathrm{C}_{2}$ (Hägg carbide) and $\theta-\mathrm{Fe}_{3} \mathrm{C}$ (cementite), could be observed in both $\mathrm{K}$ - and Ba-promoted samples, while extensive carburization was not observed in the unpromoted sample; in that case, lines related to magnetite were observed, with only minor peaks related to carbides. This rather restrict carburization was likely due to the use of diluted $\mathrm{CO}$ and $\mathrm{H}_{2}$ gas mixtures in the synchrotron experiment. Regarding the $\mathrm{K}$ and Ba-promoted samples, visual inspection does not allow for a conclusion to be drawn as to whether or not other metastable carbides $\left(\varepsilon-\mathrm{Fe}_{3} \mathrm{C}\right.$ or $\left.\eta-\mathrm{Fe}_{2} \mathrm{C}\right)$ might have formed. Interestingly, the Ba-promoted catalyst also yielded $\mathrm{BaCO}_{3}$, as observed by the diffraction peaks located at $2 \theta$ at approximately $28^{\circ}$ and $39^{\circ}$. Figure $3 \mathrm{D}$ displays the patterns obtained after $1 \mathrm{~h}$ at $270{ }^{\circ} \mathrm{C}$ under diluted $\mathrm{CO}+\mathrm{H}_{2}\left(\mathrm{H}_{2} / \mathrm{CO}\right.$ molar ratio of 0.7$)$. In contrast to the results observed for unpromoted and K-promoted catalysts, the magnetite phase virtually disappeared for the Ba-promoted catalyst, while the diffraction lines related to iron carbides became more prevalent.
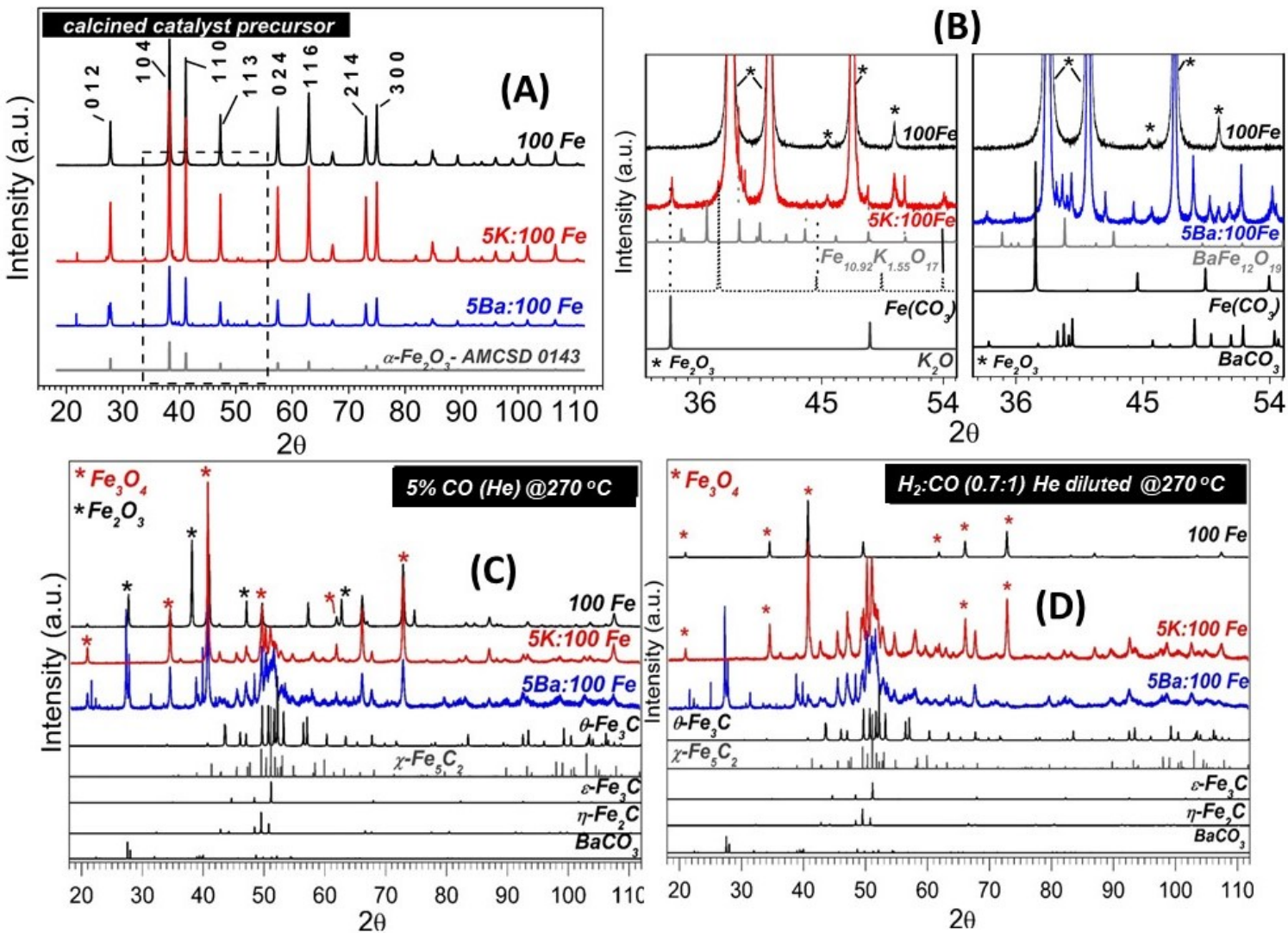

Figure 3. SXRPD patterns of the Fe-based samples after calcination (A). Blow-up of the dotted line circled area of Figure A, which displays small diffraction lines related to minor phases that were formed in the K- and Ba-promoted calcined catalyst precursors (B). After $1 \mathrm{~h}$ of carburization under 5\% CO (He diluted) flow (C) and after $1 \mathrm{~h}$ flow of exposure to a He-diluted mixture of $\mathrm{H}_{2}$ : $\mathrm{CO}(0.7: 1$ molar ratio) (D). 
SXRPD data were Rietveld-refined in order to obtain the evolution of phase composition over the carburization process of our samples considering the following phases (described in detail in Table 1): $\alpha-\mathrm{Fe}_{2} \mathrm{O}_{3}, \mathrm{Fe}_{3} \mathrm{O}_{4}, \chi-\mathrm{Fe}_{5} \mathrm{C}_{2}$, and $\theta-\mathrm{Fe}_{3} \mathrm{C}$.

Table 1. Phase models considered in the Rietveld refinement considered in this work.

\begin{tabular}{|c|c|c|c|c|c|c|}
\hline \multirow[t]{2}{*}{ Phase } & \multirow[t]{2}{*}{ Code } & \multirow[t]{2}{*}{$\begin{array}{l}\text { Space } \\
\text { Group }\end{array}$} & \multicolumn{4}{|c|}{ Unit Cell Parameters } \\
\hline & & & a $(\AA)$ & b (Å) & c (Å) & $\begin{array}{c}\beta \\
\text { (deg.) }\end{array}$ \\
\hline$\theta-\mathrm{Fe}_{3} \mathrm{C}$ & amcsd 0013523 & $\mathrm{Pnma}$ & 5.092 & 6.741 & 4.527 & \\
\hline$\chi-\mathrm{Fe}_{5} \mathrm{C}_{2}$ & COD 1521831 & $\mathrm{C} 2 / \mathrm{c}$ & 11.588 & 4.579 & 5.059 & 97.746 \\
\hline $\mathrm{Fe}_{3} \mathrm{O}_{4}$ & amcsd 0002400 & $\mathrm{~F} \mathrm{~d}-3 \mathrm{~m}$ & 8.3965 & & & \\
\hline$\alpha-\mathrm{Fe}_{2} \mathrm{O}_{3}$ & amcsd 0000143 & $R-3 c$ & 5.038 & 5.038 & 13.772 & \\
\hline $\mathrm{BaCO}_{3}$ & amcsd 0000235 & Pmcn & 5.3126 & 8.8958 & 6.4284 & \\
\hline
\end{tabular}

Figure 4 depicts the phase evolution of the unpromoted, K-promoted, and Ba-promoted samples as a function of the temperature and testing conditions. The phase transition from $\mathrm{Fe}_{2} \mathrm{O}_{3}$ to $\mathrm{Fe}_{3} \mathrm{O}_{4}$ was observed in all samples during temperature ramping under He-diluted, $5 \% \mathrm{CO}$. The addition of potassium resulted in a slight delay in the $\mathrm{Fe}_{2} \mathrm{O}_{3}$ to $\mathrm{Fe}_{3} \mathrm{O}_{4}$ transition, as be observed by the $\mathrm{Fe}_{3} \mathrm{O}_{4}$ temperature onset, which was $213^{\circ} \mathrm{C}$ and $229^{\circ} \mathrm{C}$ for the unpromoted and K-promoted samples, respectively. This shift in the $\mathrm{Fe}_{2} \mathrm{O}_{3}$ to $\mathrm{Fe}_{3} \mathrm{O}_{4}$ transition in the presence of alkalis has been observed by $\mathrm{Li}$ et al. [23] and will be further analyzed during the discussion of the temperature-programmed results. The presence of $\mathrm{Ba}$ was found to decrease the $\mathrm{Fe}_{2} \mathrm{O}_{3}$ to $\mathrm{Fe}_{3} \mathrm{O}_{4}$ reduction onset at approximately $168^{\circ} \mathrm{C}$, indicating a strong promoting effect that could be ascribed to the activation of either the $\mathrm{Fe}-\mathrm{O}$ bond (toward iron oxide reduction) or $\mathrm{C}-\mathrm{O}$ bond (toward the formation of $\mathrm{CO}_{2}$ from lattice-O). Based on Raman spectroscopy, Li et al. [30] reported that Fe-O bond strengthening caused by the presence of the alkaline-earth promoter, although $\mathrm{Sr}$ and $\mathrm{Ba}$ were found to slightly facilitate the $\mathrm{Fe}_{2} \mathrm{O}_{3}$ reduction to $\mathrm{Fe}_{3} \mathrm{O}_{4}$ caused by $\mathrm{CO}$.

There was no observable formation of phases other than magnetite in our unpromoted catalyst during treatment in either $\mathrm{CO}$ or syngas. This suggests that, at the most, only a tiny fraction of the iron oxides was transformed into an amorphous iron carbide phase under the experimental conditions adopted in this work. The K- and Ba-promoted samples displayed a greater extent of carburization, such that the final magnetite content was (after $1 \mathrm{~h}$ flowing the (He-diluted) $\mathrm{CO}+\mathrm{H}_{2}$ mixture, at $270{ }^{\circ} \mathrm{C}$ ) only about $10 \%$ and $2 \%$, respectively. In this analysis, both $\chi-\mathrm{Fe}_{5} \mathrm{C}_{2}$ and $\theta-\mathrm{Fe}_{3} \mathrm{C}$ were considered. The $\eta-\mathrm{Fe}_{2} \mathrm{C}$ and $\varepsilon-\mathrm{Fe}_{3} \mathrm{C}$ crystallographic phases, also considered in former refinements of our data, only gave trace or zero weight fractions. This strongly suggests that they did not form in our experimental conditions, at least in a noticeable quantity or as a crystalline phase. Theoretical studies $[16,38]$ have indicated that octahedral $(O)$ phases (e.g., $\eta-\mathrm{Fe}_{2} \mathrm{C}, \varepsilon-\mathrm{Fe}_{3} \mathrm{C}$ ) have slightly lower energies and therefore should be more stable than the trigonal prismatic (TP) carbides $\left(\chi-\mathrm{Fe}_{5} \mathrm{C}_{2}, \theta-\mathrm{Fe}_{3} \mathrm{C}\right.$, and the high pressure formed $\left.\mathrm{h}-\mathrm{Fe}_{7} \mathrm{C}_{3}\right)$. However, TP phases are more frequently shown to form under in situ, in operando FTS conditions as well as in spent FTS catalysts [13,39]. According to a hypothesis proposed by de Smit et al. [16], this might be ascribed to the higher entropy that these TP carbides possess in comparison to the $\mathrm{O}$ carbides. 


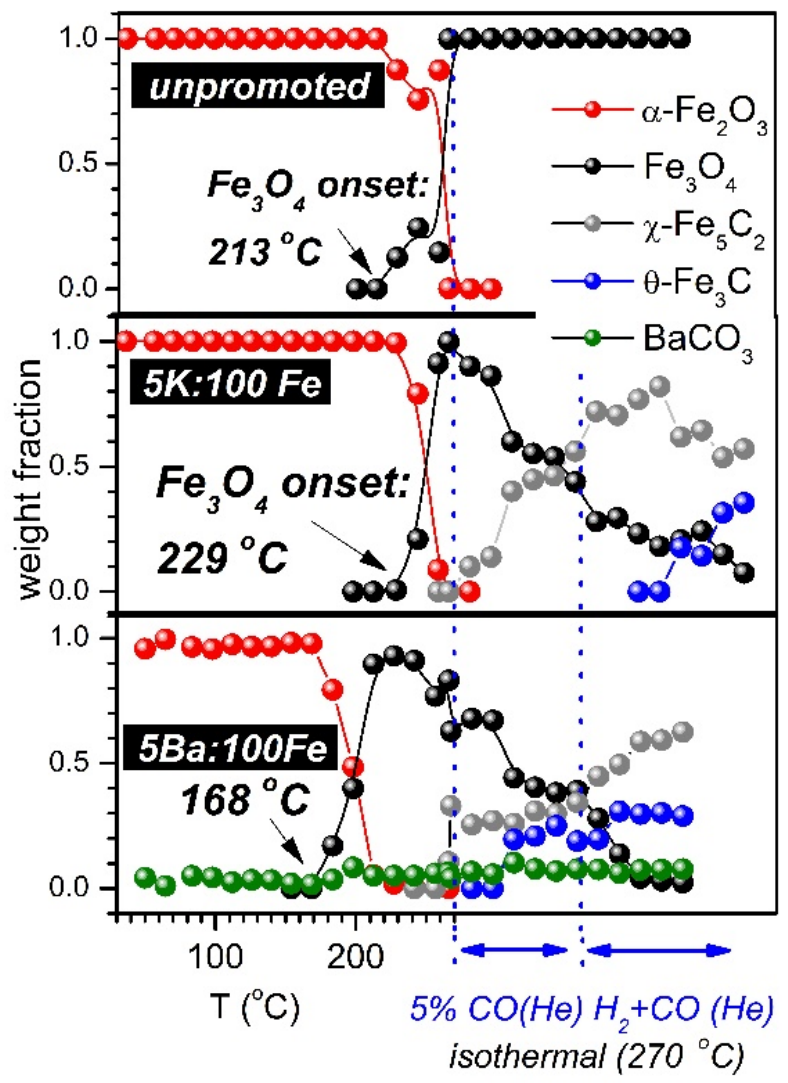

Figure 4. Evolution of catalyst phase composition as a function of the temperature and in situ testing conditions.

The evolution of the $\mathrm{Fe}_{2} \mathrm{O}_{3}$ and $\mathrm{Fe}_{3} \mathrm{O}_{4}$ a lattice parameters as a function of the temperature and gas phase composition is displayed in Figure 5A. The expected linear evolution of the cell parameters is observed in both phases during temperature ramping toward $270{ }^{\circ} \mathrm{C}$. Regarding the $\mathrm{Fe}_{2} \mathrm{O}_{3}$ phase, the fact that the slopes are similar for all of the samples suggests that there was not a significant insertion of the promoter ion into the $\mathrm{Fe}_{2} \mathrm{O}_{3}$ phase during temperature ramping. Regarding the behavior of $\mathrm{Fe}_{3} \mathrm{O}_{4}$ in the $270{ }^{\circ} \mathrm{C}$ constant temperature region, it can be noticed that larger values of the unit cell parameter are obtained for both the $\mathrm{K}$ - and Ba-promoted samples, indicating the insertion of promoter ions into the $\mathrm{Fe}_{3} \mathrm{O}_{4}$ structure, probably by substituting Fe ions for the voluminous alkali and alkaline earth ions. Interestingly, the parameter cell of the $\mathrm{Fe}_{3} \mathrm{O}_{4}$ phase in the Ba-promoted sample slightly decreased toward the values observed in the unpromoted sample during the isothermal treatment under He-diluted syngas, suggesting that the fraction of magnetite that was doped with $\mathrm{Ba}^{2+}$ ions was reduced first (towards iron carbides), yielding only small $\mathrm{Fe}_{3} \mathrm{O}_{4}$ crystallites containing lower amounts (if any) of $\mathrm{Ba}^{2+}$ ions. Likely, the $\mathrm{Ba}^{2+}$ ions present in the $\mathrm{Ba}$-doped $\mathrm{Fe}_{3} \mathrm{O}_{4}$ were being segregated towards a stable, nanocrystalline $\mathrm{BaCO}_{3}$ phase, as the magnetite phase was being consumed under diluted syngas treatment. Regarding the K-promoted sample, a slight linear increase in the $\mathrm{Fe}_{3} \mathrm{O}_{4}$ a cell parameter during isothermal treatment with diluted syngas suggests $\mathrm{K}^{+}$insertion. This nanocrystalline $\mathrm{K}-\mathrm{Fe}_{3} \mathrm{O}_{4}$ phase might be responsible [26] for the somewhat higher WGS activity displayed by the K-promoted catalyst, which is to be discussed later. 

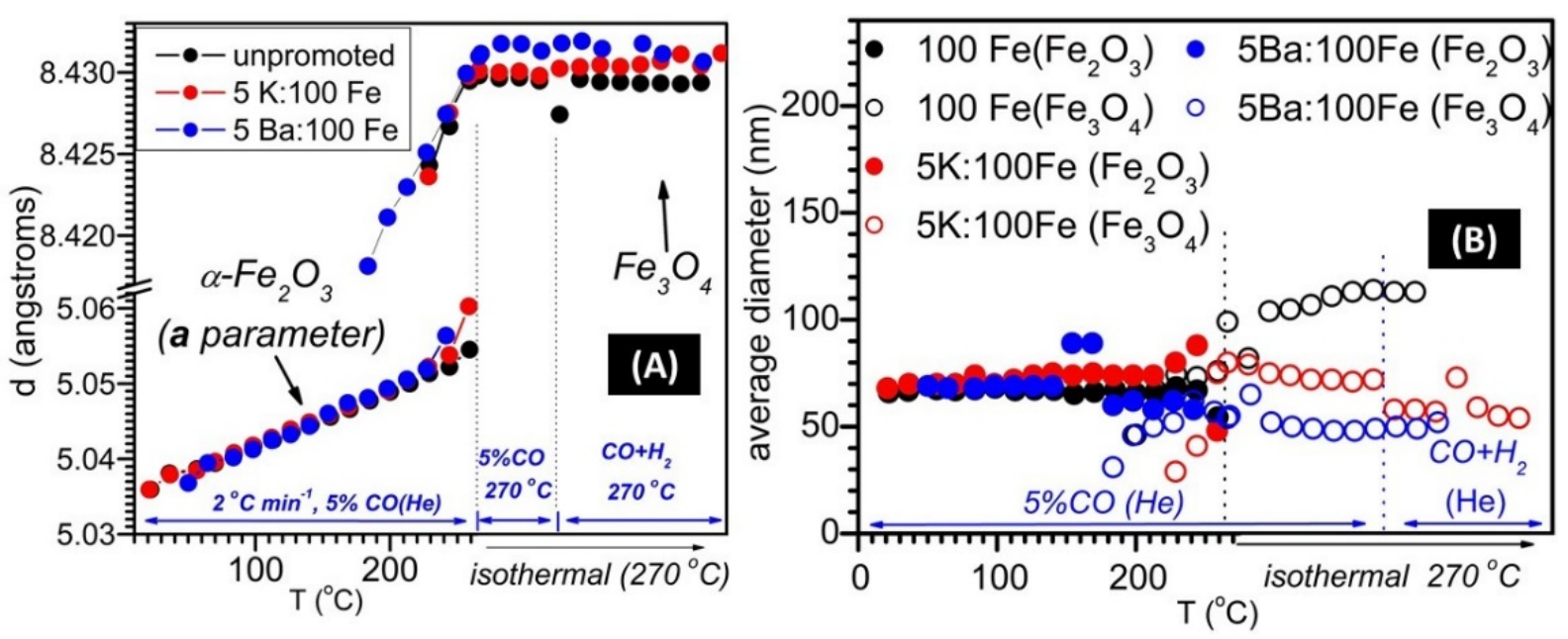

Figure 5. $\mathrm{Fe}_{2} \mathrm{O}_{3}$ and $\mathrm{Fe}_{3} \mathrm{O}_{4}$ a unit cell parameters, respectively (A), and average particle diameter (B), as a function of the temperature and in situ testing conditions.

Average crystallite sizes of the $\mathrm{Fe}_{2} \mathrm{O}_{3}$ and $\mathrm{Fe}_{3} \mathrm{O}_{4}$ phases are displayed in Figure 5B. Although the particle sizes of the hematite phase are similar in the three samples, the magnetite particles assume significantly different sizes, such that the order was: unpromoted > $5 \mathrm{~K}: 100 \mathrm{Fe}>5 \mathrm{Ba}: 100 \mathrm{Fe}$. If one considers a model whereby iron carbides grow around $\mathrm{Fe}_{3} \mathrm{O}_{4}$ nanoparticles [4] under carburization and FTS conditions in a core-shell configuration, one might rationalize this order by ascribing the smaller $\mathrm{Fe}_{3} \mathrm{O}_{4}$ particle sizes found in Ba-promoted and (to a lower extent) K-promoted catalysts to magnetite cores of variable sizes surrounded by iron carbide shells with variable thicknesses. Nevertheless, additional experiments (e.g., TEM studies) are required to further explore this hypothesis. Figure 6 summarizes the different phases formed during reduction under either $\mathrm{H}_{2}$ or $\mathrm{CO}$.
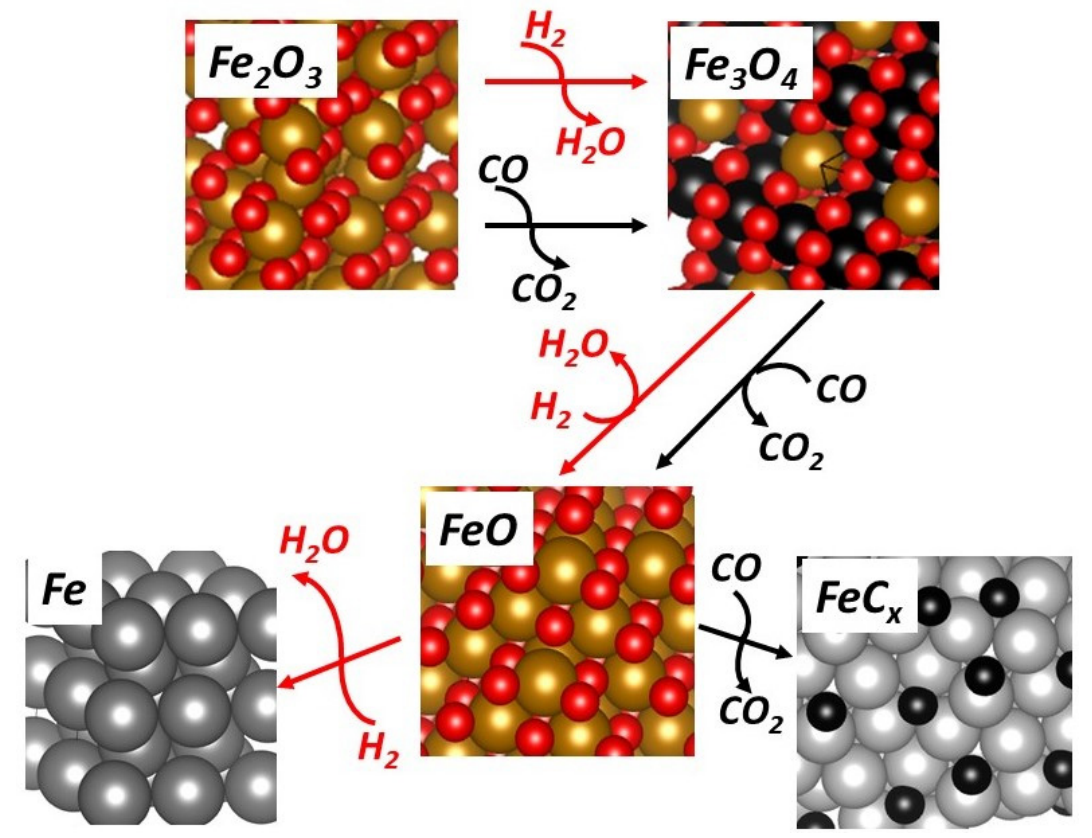

Figure 6. Phases formed during reduction under $\mathrm{H}_{2}$ and $\mathrm{CO}$ (carburization).

\subsection{Temperature-Programmed Studies}

$\mathrm{H}_{2}$-TPR profiles are reported in Figure 7A and follow a typical stepwise progression, including $3 \mathrm{Fe}_{2} \mathrm{O}_{3}+\mathrm{H}_{2} \rightarrow 2 \mathrm{Fe}_{3} \mathrm{O}_{4}+\mathrm{H}_{2} \mathrm{O} ; 2 \mathrm{Fe}_{3} \mathrm{O}_{4}+2 \mathrm{H}_{2} \rightarrow 6 \mathrm{FeO}+2 \mathrm{H}_{2} \mathrm{O} ; 6 \mathrm{FeO}+6 \mathrm{H}_{2}$ $\rightarrow 6 \mathrm{Fe}^{0}+6 \mathrm{H}_{2} \mathrm{O}$. Adding the alkali has an inhibiting effect on the first step of reduction, 
shifting it from $376{ }^{\circ} \mathrm{C}$ to $435{ }^{\circ} \mathrm{C}$ in the case of K-promotion and to $392{ }^{\circ} \mathrm{C}$ in the case of Ba-promotion. This shift toward higher temperatures in the $\mathrm{Fe}_{2} \mathrm{O}_{3}$-to- $\mathrm{Fe}_{3} \mathrm{O}_{4}$ reduction peak has also been observed by $\mathrm{Li}$ et al. $[17,23]$ and has been related to either the strengthening of Fe-O bonds or to an inhibiting effect that the promoter may have in the activation of $\mathrm{H}_{2}[17,23]$. The maxima for the latter two steps occurred over a similar temperature range (Maximum \#2: $594^{\circ} \mathrm{C}, 599^{\circ} \mathrm{C}$, and $594^{\circ} \mathrm{C}$ and Maximum \#3: $623^{\circ} \mathrm{C}, 631^{\circ} \mathrm{C}$, and $621^{\circ} \mathrm{C}$ for unpromoted, $\mathrm{K}$-promoted, and Ba-promoted, respectively).
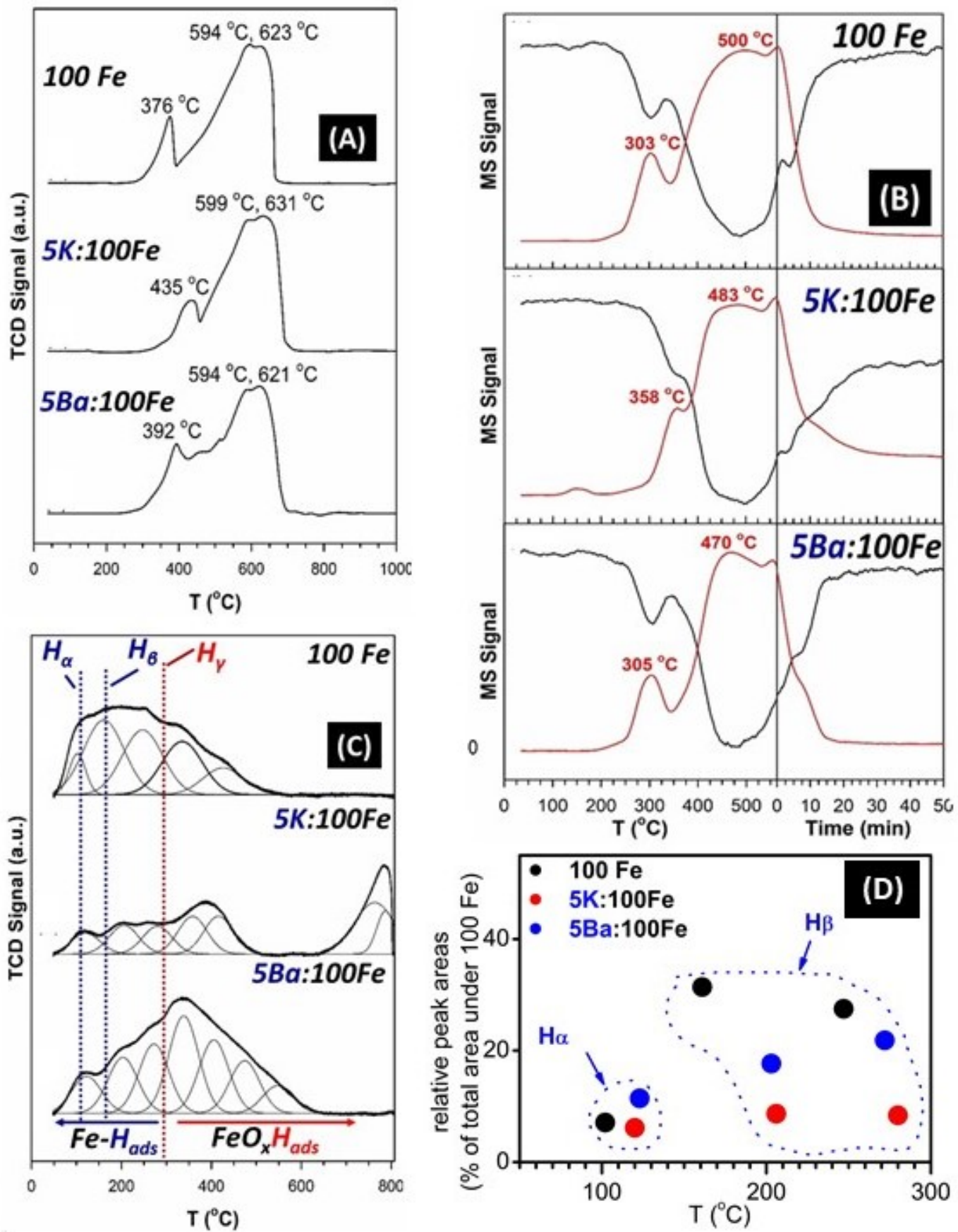

Figure 7. $\mathrm{H}_{2}$-TPR (A), CO-TPC (MS signals of (black) $\mathrm{CO}$ and (red) $\mathrm{CO}_{2}$ ) (B), H-TPD profiles (C) of the un-promoted, K-, and Ba-promoted catalysts; relative H-TPD peak areas (\% relative to the area under the unpromoted (100Fe) catalyst) (D).

In the case of CO-TPC (Figure 7B), the profiles are quite complex. The first carburization step involves converting $\mathrm{Fe}_{2} \mathrm{O}_{3}$ to $\mathrm{Fe}_{3} \mathrm{O}_{4}$, and the alkali has an inhibiting effect (maximum \#1: $303^{\circ} \mathrm{C}, 358{ }^{\circ} \mathrm{C}$, and $305^{\circ} \mathrm{C}$ for unpromoted, K-promoted, and Ba-promoted, 
respectively). The observed trend in the temperatures where the $\mathrm{Fe}_{2} \mathrm{O}_{3}$ to $\mathrm{Fe}_{3} \mathrm{O}_{4}$ transition maxima are observed is consistent with the observed $\mathrm{Fe}_{2} \mathrm{O}_{3}$ to $\mathrm{Fe}_{3} \mathrm{O}_{4}$ transition temperature onsets, as previously shown by the $\operatorname{XRD}$ data $\left(213,229\right.$, and $168{ }^{\circ} \mathrm{C}$, related to the unpromoted, $\mathrm{K}$ - and Ba-promoted samples, respectively). This trend may be rationalized in terms of alkali-promoted Fe-O bond strengthening, which is compensated for by the more facile dissociative adsorption of $\mathrm{CO}$ on an alkaline-earth-doped iron oxide surface [30]. Carburization, however, occurs more rapidly, as $\mathrm{Fe}_{3} \mathrm{O}_{4}$ passes through a defect-laden oxide resembling $\mathrm{FeO}$ and progresses further to the Fe carbide.

Based on the XRD results previously shown in Figure 4, the presence of the alkaline earth promoter seems to promote carburization more effectively. This is consistent with CO-TPC studies (Figure 7B), as there is a noticeable shift to the lower temperatures of the main $\mathrm{CO}_{2}$ evolution peak located above $380{ }^{\circ} \mathrm{C}$ : unpromoted $\left(500{ }^{\circ} \mathrm{C}\right)>\mathrm{K}$-promoted $\left(483^{\circ} \mathrm{C}\right)>$ Ba-promoted $\left(470^{\circ} \mathrm{C}\right)$.

Figure 7C displays the $\mathrm{H}_{2}$-TPD desorption profiles deconvoluted as Gaussian curves in order to estimate the different contributions lumped together under the profile areas. The unpromoted catalyst displays a broad asymmetric peak containing various contributions below $560{ }^{\circ} \mathrm{C}$, including approximately $100{ }^{\circ} \mathrm{C}, 167,250{ }^{\circ} \mathrm{C}, 323^{\circ} \mathrm{C}$, and $424{ }^{\circ} \mathrm{C}$. With the addition of $\mathrm{K}$, the asymmetric cluster of peaks below $560^{\circ} \mathrm{C}$ was suppressed. These peaks included those at $117^{\circ} \mathrm{C}, 203^{\circ} \mathrm{C}, 263^{\circ} \mathrm{C}$, and $336^{\circ} \mathrm{C}$. In addition, there was an intense peak at a high temperature, $783^{\circ} \mathrm{C}$. With the addition of $\mathrm{Ba}$, the cluster of peaks was broadened to $650{ }^{\circ} \mathrm{C}$. The peaks included $117^{\circ} \mathrm{C}, 203{ }^{\circ} \mathrm{C}, 263^{\circ} \mathrm{C}$, and $336{ }^{\circ} \mathrm{C}$ along with a few further contributions extending up to approximately $650^{\circ} \mathrm{C}$. The multiplicity of peaks indicates the existence of $\mathrm{H}$ adsorption surface sites of various strengths. In fact, $\mathrm{H}$-desorption studies made on clean Fe surfaces revealed the existence of two broad desorption peaks located below $200{ }^{\circ} \mathrm{C}$ and within the $200-300{ }^{\circ} \mathrm{C}$ range, designated as $\mathrm{H}_{\alpha}$ and $\mathrm{H}_{\beta}$ [23], which have been correlated with adsorbed $\mathrm{H}$ on differently coordinated Fe surface sites. The desorption peaks located above $300{ }^{\circ} \mathrm{C}$ are related to the decomposition of the hydroxyl groups located on unreduced surface sites. Figure 7D displays the relative peak areas, as a percentage of the total area of the $100 \mathrm{Fe}$ (unpromoted) H-TPD profile. Assuming that the areas are proportional to the amount of $\mathrm{H}$ desorbed, it can be clearly seen that while the areas related to the loosely chemisorbed $\mathrm{H}$ (around $120{ }^{\circ} \mathrm{C}$ ) are about the same among the three catalyst samples (perhaps with a little enhancement due to $\mathrm{Ba}$ ), the areas related to more strongly adsorbed $\mathrm{H}$ (hollow fourfold surface sites and defects $[23,40]$ ) are suppressed by the presence of $\mathrm{Ba}^{2+}$ and, to an even larger extent, $\mathrm{K}^{+}$. This suppression might be explained in terms of an electronic effect where the ionic promoter valence levels mix with incomplete Fe $3 \mathrm{~d}$ levels, thus increasing the activation energy necessary to adsorb $\mathrm{H}_{2}$ and form the Fe-H bond, mainly via electronic repulsion [40].

\subsection{BET Results}

As shown in the Table S1, the BET surface areas (12.5-14.2 $\left.\mathrm{m}^{2} / \mathrm{g}\right)$, BJH pore volumes $\left(0.11-0.12 \mathrm{~cm}^{3} / \mathrm{g}\right)$, and pore diameters $(31-33 \mathrm{~nm})$ were similar among the catalysts.

\subsection{FTS Catalyst Testing}

Unpromoted, K-promoted, and Ba-promoted catalysts were tested at typical FTS process conditions for more than $200 \mathrm{~h}$. Figure 8 shows that both $\mathrm{CO}$ and $\mathrm{H}_{2}$ conversions decrease with time on-synthesis (TOS) for all three catalysts. The K-promoted Fe-catalyst displayed a CO conversion of about $73 \%$ at $24 \mathrm{~h}$, which then decreased rapidly to $60 \%$ at $100 \mathrm{~h}$ and then decreased further to $35 \%$ after $200 \mathrm{~h}$. The $\mathrm{H}_{2}$ conversion shows a similar trend to that of $\mathrm{CO}$ conversion. The unpromoted Fe catalyst exhibits a steady hydrogen conversion over $200 \mathrm{~h}$, while it displayed a decrease in the conversion of CO during the same period. The $\mathrm{CO}$ conversion trend for the Ba-promoted Fe catalysts followed that of unpromoted Fe but was $5-10 \%$ lower. This indicates that the K promoter influences the catalyst deactivation rate moreso than $\mathrm{Ba}$ does at the promoter loadings used in this work (5Me:100Fe, atomic ratio). This is consistent with the results reported by Luo and 
Davis [31]. It is well-known that the presence of $\mathrm{K}$ facilitates substantial carbon formation on the catalyst surface during CO activation and FTS [41]. These carbon fringes have a direct impact on catalyst stability depending on their structure and location, which is expected to alter the conversion and product selectivity during FTS. In agreement with the $\mathrm{H}_{2}$-TPR and H-TPD trends, the addition of potassium suppresses hydrogen activation. On the other hand, $\mathrm{K}$ is known to enhance dissociative $\mathrm{CO}$ adsorption on $\mathrm{Fe}$, which likely results in carbon accumulation over the catalyst surfaces covering the active iron carbides either partially or completely [42]. Using TPR/XANES, Ribeiro et al. [5] observed an increase in the extent of carburization in alkali-promoted Fe catalysts, which is related to an enhancement in the $\mathrm{CO}$ dissociation rate. Earlier, Arakawa and Bell [43] found that potassium increases the rate of catalyst carburization as well as the water-gas shift activity.

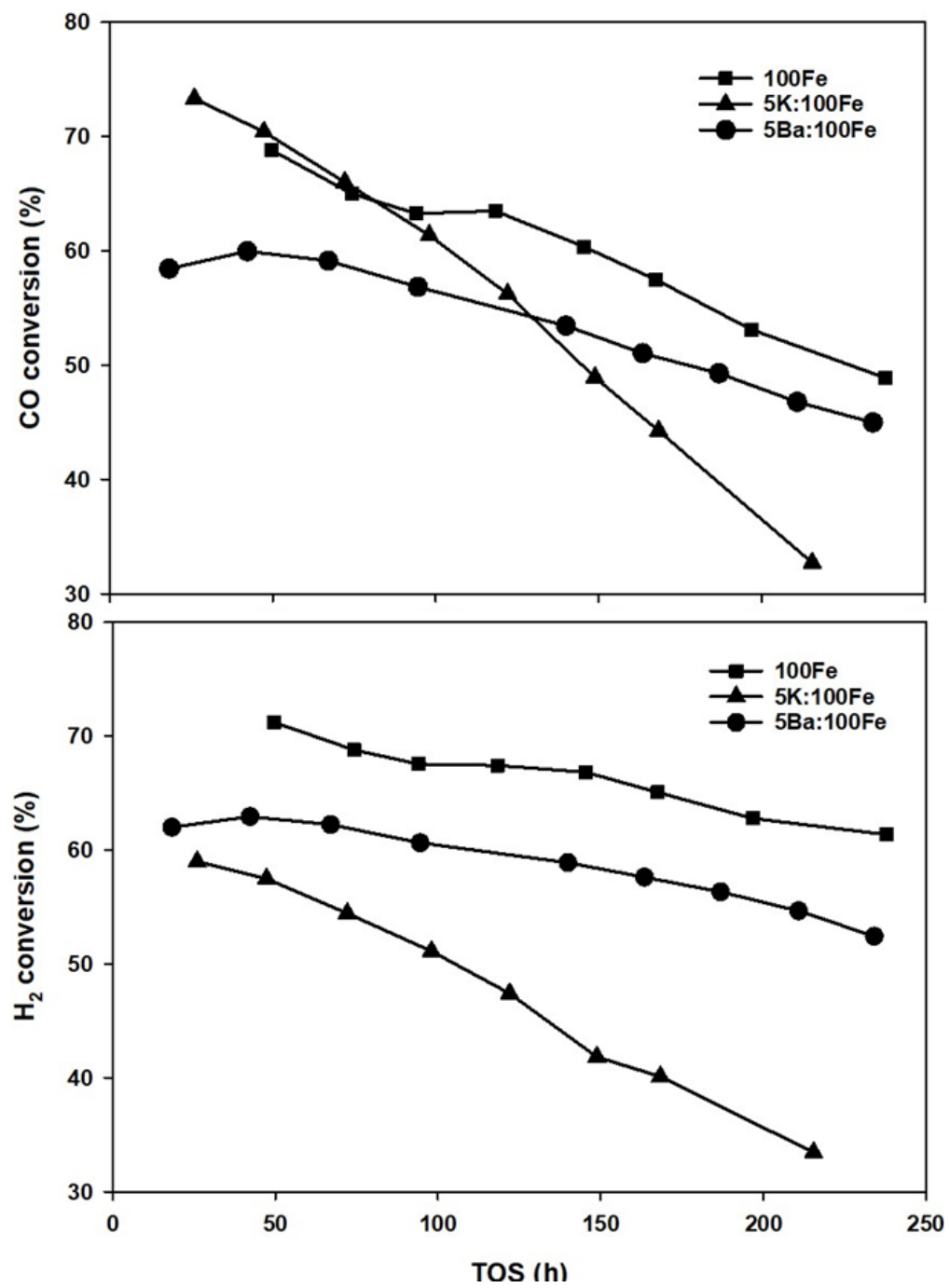

Figure 8. $\mathrm{CO}$ (top) and $\mathrm{H}_{2}$ conversions (bottom) as a function of time on-synthesis for Fe catalysts.

The selectivities to methane and $\mathrm{CO}_{2}$ of the various catalysts are shown in Figure 9. Both unpromoted and Ba-promoted Fe catalysts show about the same methane selectivity, which is in the range of 5-6.5 mol\% over the course of $200 \mathrm{~h}$ of FT synthesis. In contrast, K-promoted Fe produced methane as low as $3 \mathrm{~mol} \%$, approximately half of that which evolved from the pure $\mathrm{Fe}$ and Ba-promoted Fe catalysts. $\mathrm{CO}_{2}$ selectivity represents the catalyst activity for the WGS reaction. The promoter effects on the WGS activity of Fe follow the order $5 \mathrm{~K}: 100 \mathrm{Fe}>5 \mathrm{Ba}: 100 \mathrm{Fe}>100 \mathrm{Fe}$. 


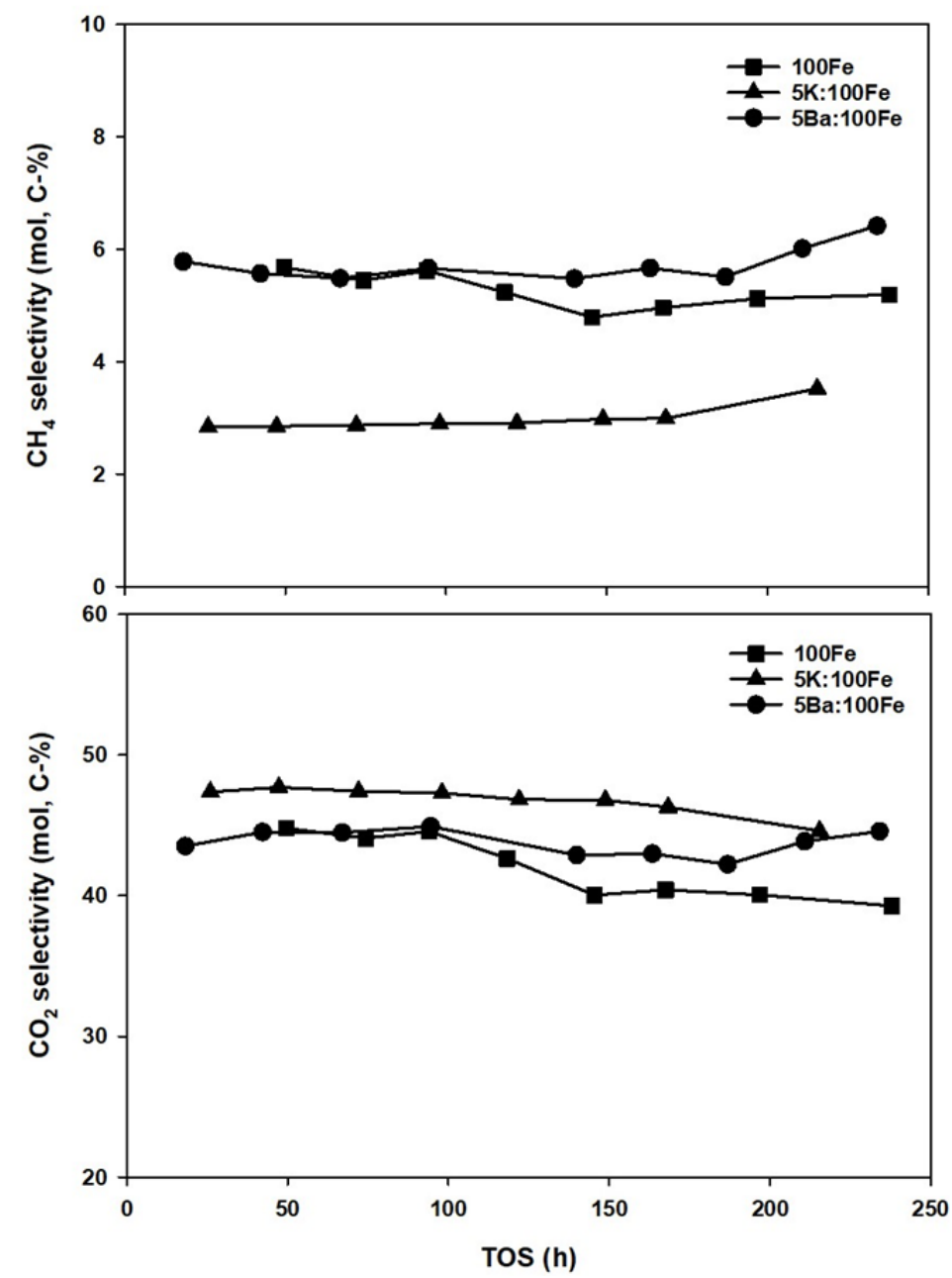

Figure 9. $\mathrm{CH}_{4}$ (top) and $\mathrm{CO}_{2}$ (bottom) selectivity as a function of time on-synthesis for Fe-catalysts.

Davis et al. [44] pointed out that potassium increases WGS activity and that there is an optimum $\mathrm{K}$ loading that is necessary to achieve maximum syngas conversion. Overall, FTS activity depends on both FTS and WGS reactions, as the latter would provide hydrogen that is needed for Fe-based FTS. In this regard, all three Fe catalysts showed some deactivation; in particular, the K-promoted Fe catalyst lost most of its activity, and this was accompanied by a slight decrease in the WGS selectivity after $100 \mathrm{~h}$ of TOS.

Anderson-Schulz-Flory (ASF) plots for hydrocarbons and oxygenates are shown in Figure 10. The sharp decline at the $\mathrm{C}_{5}$-carbon in the case of hydrocarbons is attributed to volatile product losses during liquid sampling and during sample preparation for GC analysis. Hence, only the carbon numbers from $C_{9}$ to $C_{21}$ are considered for determining the alpha value. The alpha of hydrocarbons for the $100 \mathrm{Fe}$ catalyst is 0.72 , while it was higher for the promoted catalysts: 0.84 and 0.76 for $5 \mathrm{~K}: 100 \mathrm{Fe}$ and $5 \mathrm{Ba}: 100 \mathrm{Fe}$, respectively. Without any additional structural promoters, $\mathrm{K}$ and Ba seem to not significantly influence the chain growth probability of oxygenates $(\sim 0.73)$. They mainly impact the hydrocarbon distribution and the selectivity to olefins. This is in agreement with the literature [44]. The co-feeding experiments with the Fe catalysts for FTS suggest that both 1-olefin and oxygenates take part in the secondary reactions that may increase chain growth probability. It has been pointed out by many authors that 1-olefins and oxygenates both follow a similar trend with respect to chain propagation. However, there is a debate in the discussion of the reaction pathways for oxygenates (CO insertion versus hydroxy carbene) and the degree to which alcohols and olefins undergo reincorporation. The pioneering work from Kummer and Emmett [45] (later summarized by Davis and Jacobs [46]) showed from 
radioactive tracer experiments that the alcohol acts as an initiator for FTS over iron catalysts. Potassium was found to suppress the secondary reactions of olefins and thereby increased olefin formation over the 100Fe:5.1Si:2Cu:(1.25 or 3.0)K catalyst [47]. In this work, the chain growth probability factor $(\alpha)$ increased for olefins with an alkali addition over iron, supporting previous findings. On the other hand, both $\mathrm{K}$ and Ba had no effect on the alpha value obtained for oxygenates, and an explanation requires further research.
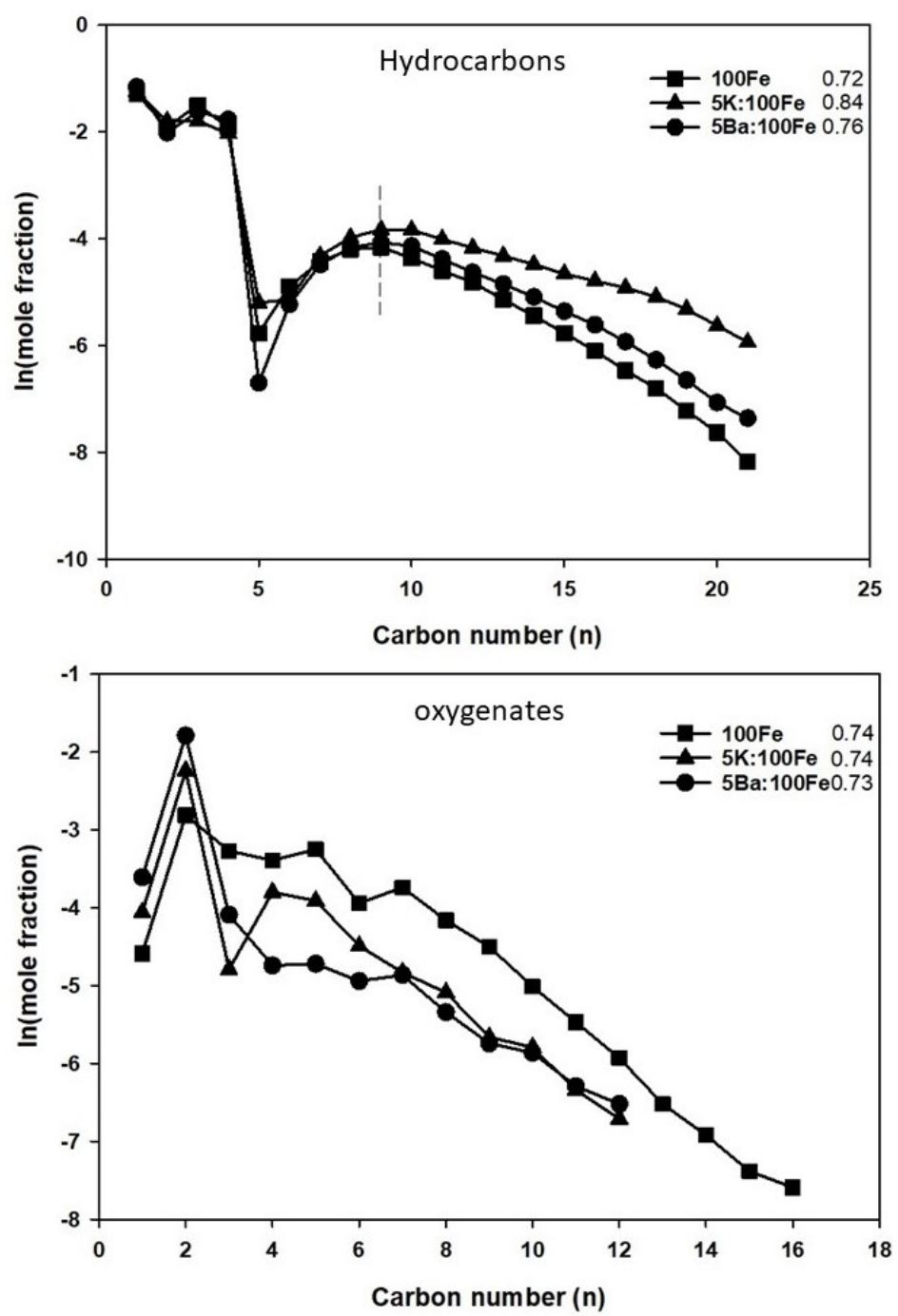

Figure 10. ASF plots for hydrocarbons (top) and oxygenates (bottom).

Table 2 shows FTS product selectivity for different Fe catalysts. Comparing selectivity at similar conversion levels provides a more valid comparison. Here, the $\mathrm{CO}$ conversion was kept within a narrow range (CO: $59.1-63.3 \%, \mathrm{H}_{2}$ : $\left.51.1-67.6 \%\right)$ in order to provide this comparison. Therefore, at similar CO conversion levels, the K-promoted Fe catalyst exhibited higher olefin selectivity and lower oxygenate and paraffin selectivities compared to unpromoted iron. Ba-promoted iron produced slightly higher paraffin selectivity compared to unpromoted iron oxide; however, the olefin content essentially remained the same. These data indicate that Ba-promotion to iron for FTS is marginal compared to K-promotion, with potassium being the generally preferred promoter. 
Table 2. The conversion and product selectivity of Fe-Fischer-Tropsch synthesis.

\begin{tabular}{cccccccccc}
\hline \multirow{2}{*}{ Catalysts } & \multicolumn{2}{c}{ Conv. (\%) } & \multicolumn{2}{c}{ Selectivity (mol, C-\%) } & \multicolumn{2}{c}{$\alpha$-Value } \\
\cline { 2 - 10 } & $\mathbf{C O}$ & $\mathbf{H}_{\mathbf{2}}$ & paraffin $^{\mathbf{a}}$ & olefin $^{\mathbf{b}}$ & oxy. $^{\mathbf{c}}$ & unident. $^{\mathbf{d}}$ & Hyd. ${ }^{\mathbf{2}}$ & Oxy. $^{\mathbf{f}}$ \\
\hline 100Fe & 63.3 & 67.6 & 30.5 & 50.4 & 7.4 & 11.7 & 0.72 & 0.74 \\
\hline $5 \mathrm{~K}: 100 \mathrm{Fe}$ & 61.4 & 51.1 & 20.8 & 62.0 & 4.5 & 12.7 & 0.84 & 0.74 \\
\hline 5Ba:100Fe & 59.1 & 62.2 & 35.5 & 51.1 & 3.6 & 51.1 & 0.76 \\
\hline
\end{tabular}

${ }^{a}$ paraffin includes just $n$-paraffin; ${ }^{b}$ olefin includes 1-olefin, cis-2-olefin, and trans-2-olefin; ${ }^{c}$ oxygenate includes alcohols only; ${ }^{\mathrm{d}}$ unidentified are the FT products including iso-paraffin, isoalkenes, and oxygenates other than alcohols; ${ }^{e}$ chain growth probability for hydrocarbons with carbon number $C_{9}-C_{21} ;{ }^{f}$ chain growth probability for oxygenates with carbon number $C_{1}-C_{12}$.

The olefin/paraffin ratio as a function of carbon number products for Fe-FTS is shown in Figure 11. Lower olefins such as $C_{2}, C_{3}$, and $C_{4}$ contribute significantly to the total olefins formed on all three catalysts. Higher olefin-to-paraffin ratios were obtained with $5 \mathrm{~K}: 100 \mathrm{Fe}$ over the entire carbon number range observed in this study, whereas both unpromoted and Ba-promoted samples showed a similar trend, both producing less olefinic products in comparison to $5 \mathrm{~K}: 100 \mathrm{Fe}$.

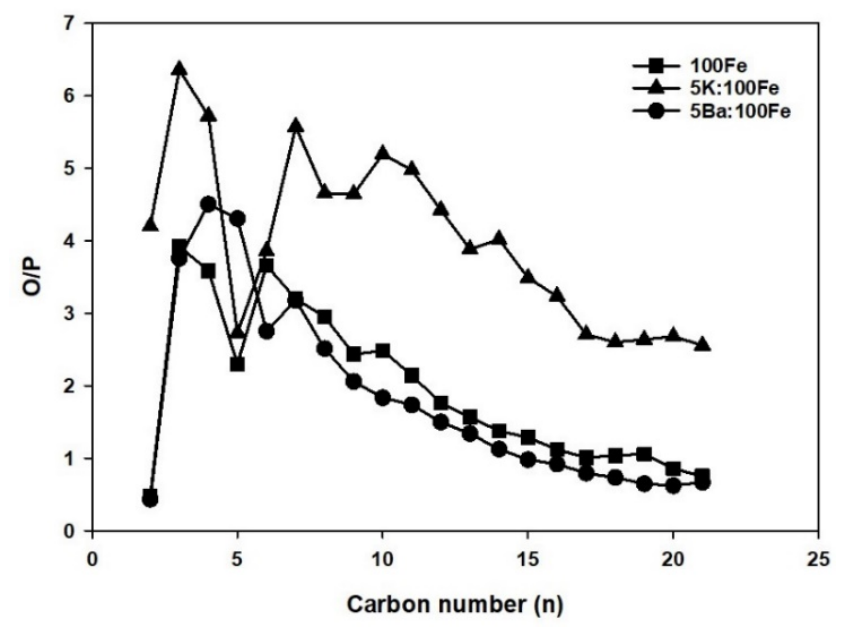

Figure 11. Olefin/paraffin as a function of carbon number.

\section{Discussion}

The presence of Ba resulted in a somewhat less active catalyst in comparison to the K-promoted catalyst. Regarding the selectivities, the heavy alkaline earth promoter, $\mathrm{Ba}$, played a less active role than $\mathrm{K}$, leading to lower $\alpha$-values and higher methane selectivies. There is a general picture that points to a correlation between promoter basicity, high carburization rates, and higher selectivities toward heavier products [5]. Furthermore, it is understood that $\mathrm{K}$ depresses the population of adsorbed $\mathrm{H}$ species by inductively increasing electron density in the Fe $3 \mathrm{~d}$ levels located within its neighborhood and therefore increases the barrier for the adsorption of the $\mathrm{H}_{2}$ molecule on the active sites [23,40]. Interestingly, our SXRD results showed that Ba induced a higher carburization extent than $\mathrm{K}$, indicating that $\mathrm{Ba}$ is in fact more active than $\mathrm{K}$ in the enhancement of $\mathrm{CO}$ dissociative adsorption rates. However, the fact that part of the $\mathrm{Ba}^{2+}$ was kept "buried" in a rather stable, crystalline $\mathrm{BaCO}_{3}$ phase might potentially prevent a fraction of the alkaline-earth ion to be available to exert any promoting effect on FTS. Nevertheles, the amount of the promoter (5Me:100 Fe) used in this work was chosen to be somewhat higher than what is usually found either in the literature or in technical Fe-based FTS catalysts (ranging from 0.3 to $3 \mathrm{Me}: 100 \mathrm{Fe} ; \mathrm{Me}=$ $\mathrm{K}-\mathrm{Ba}$ ) in order to minimize the effect of eventual differences in the promoter dispersion on catalyst performance. In other words, we expect that both $\mathrm{K}$ and Ba being in excess in the catalyst should minimize the effect of differences in dispersion and as such facilitate a 
comparison between them. On this basis, the observed differences between $\mathrm{K}$ and $\mathrm{Ba}$ as promoters might allow some discussion in terms of the intrinsic activity of $\mathrm{Ba}^{2+}$ compared to $\mathrm{K}^{+}$regarding their relative effects on FTS selectivities.

Figure 12 displays $\mathrm{Ba}^{2+} 5 \mathrm{p}^{6} 6 \mathrm{~s}^{0}, \mathrm{~K}^{+} 3 \mathrm{p}^{6} 4 \mathrm{~s}^{0}$ and $\mathrm{Fe}^{0} 3 \mathrm{~d}^{6} 4 \mathrm{~s}^{2}$ valence level energies [48]. Although more complicated interactions between the promoter and Fe $3 \mathrm{~d}$ levels should be expected, it is important to note that $\mathrm{K}^{+} 3 \mathrm{p}$ levels, which are somewhat closer in energy to Fe $3 d$ levels, should be able to interact with the metal $3 d$ states more effectively than they can with $\mathrm{Ba} 5 \mathrm{p}$ levels. The difference between $\mathrm{Ba}^{2+}$ and $\mathrm{K}^{+} \mathrm{np}$ levels apparently did not prevent $\mathrm{Ba}^{2+}$ from more effectively promoting the dissociative adsorption of $\mathrm{CO}$. However, this difference apparently did exert some influence on the $\mathrm{H}_{2}$ dissociative adsorption and likely key chain growth processes in FTS. In that sense, $\mathrm{Ba}^{2+} 5 \mathrm{p}-\mathrm{Fe} 3 \mathrm{~d}$ mixing, unlike $\mathrm{K}^{+}$ $3 \mathrm{p}-\mathrm{Fe} 3 \mathrm{~d}$ mixing, is not enough to decrease $\mathrm{H}$ adsorption via increased repulsion between the $\mathrm{H}_{2}$ molecule and Fe active sites [23,40]. Therefore, lower chain growth probabilities and higher methane selectivities were observed for the Ba-promoted catalyst in comparison with the K-promoted catalyst.

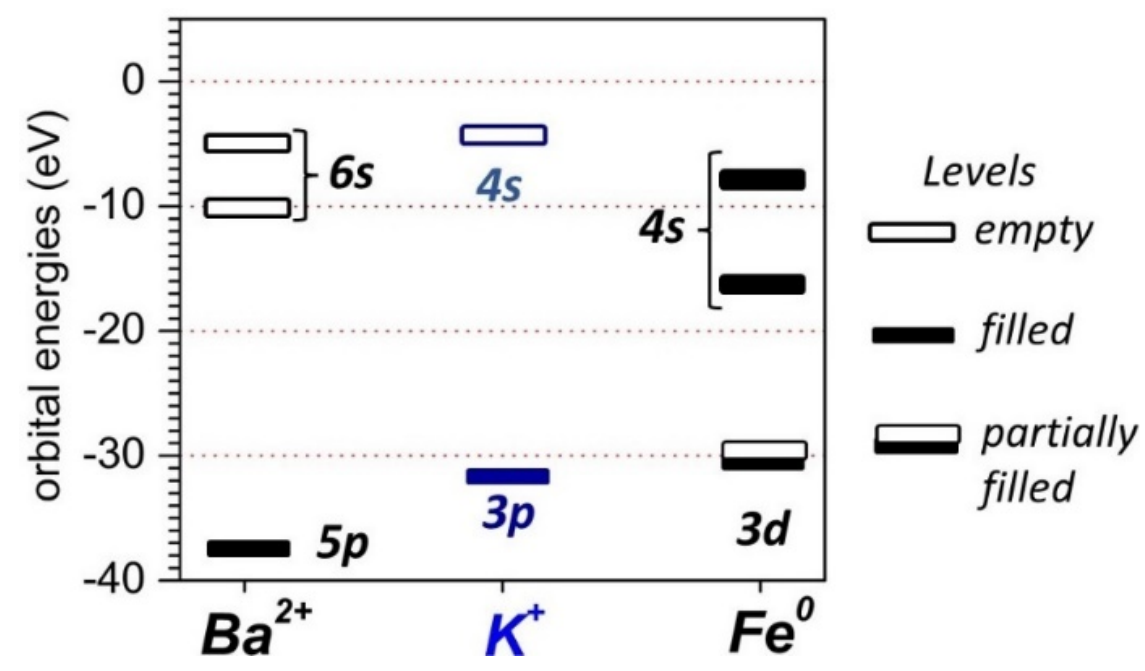

Figure 12. Atomic Ba 5p, K 3p, and Fe 3d energy levels based on ionization potentials [48].

\section{Conclusions}

In the present contribution, the effect of the promoter's ionic charge and valence states on structure-activity relationships in Fe-based FTS catalysts was examined. Although displaying formally lower basicity than $\mathrm{K}$ (comparable ionic radius, but with double ionic charge), the addition of $\mathrm{Ba}^{2+}$ surprisingly resulted in increased carburization rates. However, this effect did not lead to either increased overall catalyst activity or enhanced chain growth rates (alpha values) and olefin selectivities, as observed for our K-promoted sample. The most apparent effect of the ionic charge of the promoter was the formation of a stable $\mathrm{BaCO}_{3}$ phase in our catalysts (as shown by SXRD). This may indicate that the potentially better performance of $\mathrm{Ba}^{2+}$ might be merely leveled off by the inevitable formation of a stable layer of $\mathrm{BaCO}_{3}$ that may act negatively both by pore clogging/active site inhibition or by keeping $\mathrm{Ba}^{2+}$ from being available at the catalyst surface. Even though a formal comparison between $\mathrm{K}^{+}$and $\mathrm{Ba}^{2+}$ was therefore somewhat precluded by partial $\mathrm{Ba}^{2+}$ encapsulation as a stable $\mathrm{BaCO}_{3}$ phase, the remaining $\mathrm{Ba}^{2+}$ available in the catalyst surface was not prevented from promoting the dissociative adsorption of $\mathrm{CO}$ more effectively than $\mathrm{K}^{+}$. The fact that $\mathrm{H}_{2}$ adsorption on $\mathrm{Fe}^{0}$ surface sites was not depressed as effectively by $\mathrm{Ba}^{2+}$ compared to $\mathrm{K}^{+}$, (thus resulting in the higher selectivities to methane and light products observed in the Ba-promoted catalyst) indicates that the charge transfer between the promoter and the catalyst active sites, postulated to be the main promotion mechanism, is not as effective between $\mathrm{Ba}^{2+} 5 \mathrm{p}-\mathrm{Fe} 3 \mathrm{~d}$ states as it is between $\mathrm{K}^{+} 3 \mathrm{p}-\mathrm{Fe} 3 \mathrm{~d}$ states. This is likely due to differences in their relative energies. 
Supplementary Materials: The following are available online at https:/ /www.mdpi.com/article/10 $.3390 /$ reactions2040026/s1, Table S1: BET surface area and pore size distribution.

Author Contributions: Conceptualization, investigation, visualization, M.Z.L.L.R.; investigation and formal analysis, J.C.S.; investigation, formal analysis, and writing, M.K.G.; investigation, visualization, formal analysis, conceptualization, and writing, M.M.; investigation, visualization, and formal analysis, G.F.U.; conceptualization, investigation, visualization, formal analysis, supervision, and writing, G.J.; conceptualization, investigation, visualization, formal analysis, supervision, and writing, M.C.R. All authors have read and agreed to the published version of the manuscript.

Funding: This research received no external funding.

Acknowledgments: CAER research was supported by the Commonwealth of Kentucky. Gabe Upton would like to acknowledge support from the UTSA College of Engineering. Gary Jacobs would like to thank UTSA and the State of Texas for financial support through startup funds. This research used resources from the Brazilian Synchrotron Light Laboratory (LNLS), an open national facility operated by the Brazilian Centre for Research in Energy and Materials (CNPEM) for the Brazilian Ministry for Science, Technology and Innovations (MCTI). The XPD beamline staff is acknowledged for their assistance during the experiments (project number XPD 20160477). Mauro Ribeiro thanks the ICEx-UFF, Department of Chemistry for providing some of the reactants used in the catalyst synthesis.

Conflicts of Interest: The authors declare no conflict of interest.

\section{References}

1. van de Loosdrecht, J.; Botes, F.G.; Ciobica, I.M.; Ferreira, A.C.; Gibson, P.; Moodley, D.J.; Saib, A.M.; Visagie, J.L.; Weststrate, C.J.; Niemantsverdriet, J.W. Fischer-Tropsch synthesis: Catalysts and chemistry. In Comprehensive Inorganic Chemistry II: From Elements to Applications; Surface Inorganic Chemistry and Heterogeneous Catalysis; Reedijk, J., Poeppelmeier, K., Eds.; Elsevier: Amsterdam, The Netherlands, 2013; Volume 7.20, pp. 525-557.

2. Suo, H.; Wang, S.; Zhang, C.; Xu, J.; Wu, B.; Yang, Y.; Xiang, H.; Li, Y.W. Chemical and structural effects of silica in iron-based Fischer-Tropsch synthesis catalysts. J. Catal. 2012, 286, 111-123. [CrossRef]

3. Chernavskii, P.A.; Kazak, V.O.; Pankina, G.V.; Perfiliev, Y.D.; Li, T.; Virginie, M.; Khodakov, A.Y. Influence of copper and potassium on the structure and carbidisation of supported iron catalysts for Fischer-Tropsch synthesis. Catal. Sci. Technol. 2017, 7, 2325-2334. [CrossRef]

4. de Smit, E.; Weckhuysen, B.M. The renaissance of iron-based Fischer-Tropsch synthesis: On the multifaceted catalyst deactivation behavior. Chem. Soc. Rev. 2008, 37, 2758-2781. [CrossRef] [PubMed]

5. Ribeiro, M.C.; Jacobs, G.; Davis, B.H.; Cronauer, D.C.; Kropf, A.J.; Marshall, C.L. Fischer-Tropsch synthesis: An in-situ TPREXAFS/XANES investigation of the influence of Group I alkali promoters on the local atomic and electronic structure of carburized iron/silica catalysts. J. Phys. Chem. C 2010, 114, 7895-7903. [CrossRef]

6. Gnanamani, M.K.; Hamdeh, H.H.; Jacobs, G.; Shafer, W.D.; Sparks, D.E.; Davis, B.H. Fischer-Tropsch Synthesis Activity and Selectivity of $\chi$-Fe5C2 and $\theta$-Fe3C Carbides. In Fischer-Tropsch Synthesis, Catalysts, and Catalysis; Davis, B.H., Occelli, M., Eds.; CRC Press: Boca Raton, FL, USA, 2016; pp. 15-30.

7. Nagakura, S. Study of Metallic Carbides by Electron Diffraction. Part III: Iron Carbides. J. Phys. Soc. Jpn. 1959, 14, 186-195. [CrossRef]

8. Raupp, G.B.; Delgass, W.N. Mössbauer investigation of supported Fe and FeNi catalysts: II. Carbides formed Fischer-Tropsch synthesis. J. Catal. 1979, 58, 348-360. [CrossRef]

9. Paalanen, P.P.; van Vreeswijk, S.H.; Dugulan, A.I.; Weckhuysen, B.M. Identification of Iron Carbides in Fe(Na-S)/ $\alpha$-Al2O3 Fischer-Tropsch Synthesis Catalysts with X-ray Powder Diffractometry and Mössbauer Absorption Spectroscopy. ChemCatChem 2020, 12, 5121-5139. [CrossRef]

10. Herranz, T.; Rojas, S.; Perez-Alonso, F.J.; Ojeda, M.; Terreros, P.; Fierro, J.L.G. Genesis of iron carbides and their role in the synthesis of hydrocarbons from synthesis gas. J. Catal. 2006, 243, 199-211. [CrossRef]

11. Eckstrom, H.C.; Adcock, W.A. A New Iron Carbide in Hydrocarbon Synthesis Catalysts. J. Am. Chem. Soc. 1950, 72, 1042-1043. [CrossRef]

12. Datye, A.K.; Jin, Y.; Mansker, L.; Motjope, R.T.; Dlamini, T.H.; Coville, N.J. The nature of the active phase in iron Fischer-Tropsch catalysts. Stud. Surf. Sci. Catal. 2000, 130, 1139-1144.

13. Chang, Q.; Zhang, C.; Liu, C.; Wei, Y.; Cheruvathur, A.V.; Dugulan, A.I.; Niemantsverdriet, J.W.; Liu, X.; He, Y.; Qing, M.; et al. Relationship between iron carbide phases $(\varepsilon-\mathrm{Fe} 2 \mathrm{C}, \mathrm{Fe} 7 \mathrm{C} 3$, and $\chi-\mathrm{Fe} 5 \mathrm{C} 2)$ and catalytic performances of $\mathrm{Fe} / \mathrm{SiO} 2 \mathrm{Fischer}-\mathrm{Tropsch}$ catalysts. ACS Catal. 2018, 8, 3304-3316. [CrossRef]

14. Paalanen, P.P.; Weckhuysen, B.M. Carbon pathways, sodium-sulphur promotion and identification of iron carbides in iron-based Fischer-Tropsch synthesis. Chem CatChem 2020, 12, 4202-4223. [CrossRef] 
15. de Smit, E.; Beale, A.M.; Nikitenko, S.; Weckhuysen, B.M. Local and long-range order in promoted iron-based Fischer-Tropsch catalysts: A combined in situ x-ray absorption spectroscopy/wide angle x-ray scattering study. J. Catal. 2009, 262, 244-256. [CrossRef]

16. de Smit, E.; Cinquini, F.; Beale, A.M.; Safonova, O.V.; van Beek, W.; Sautet, P.; Weckhuysen, B.M. Stability and reactivity of $\epsilon-\chi-\theta$ iron carbide catalyst phases in Fischer-Tropsch synthesis: Controlling $\mu$ C. J. Am. Chem. Soc. 2010, 132, 14928-14941. [CrossRef] [PubMed]

17. Li, J.; Cheng, X.; Zhang, C.; Yang, Y.; Li, Y.W. Effects of alkali on iron-based catalysts for Fischer-Tropsch synthesis: CO chemisorption study. J. Mol. Catal. A Chem. 2015, 396, 174-180. [CrossRef]

18. Zhang, C.; Zhao, G.; Liu, K.; Yang, Y.; Xiang, H.; Li, Y.W. Adsorption and reaction of CO and hydrogen on iron-based FischerTropsch synthesis catalysts. J. Mol. Catal. A Chem. 2010, 328, 35-43. [CrossRef]

19. Zhao, S.; Liu, X.-W.; Huo, C.F.; Li, Y.W.; Wang, J.; Jiao, H. The role of potassium promoter in surface carbon hydrogenation on Hägg carbide surfaces. Appl. Catal. A Gen. 2015, 493, 68-76. [CrossRef]

20. Jacobs, G.; Pendyala, V.R.R.; Martinelli, M.; Shafer, W.D.; Gnanamani, M.K.; Khalid, S.; MacLennan, A.; Hu, Y.; Davis, B.H. Fischer-Tropsch synthesis: XANES spectra of potassium in promoted precipitated iron catalysts as a function of time on-stream. Catal. Lett. 2017, 147, 1861-1870. [CrossRef]

21. Sarkar, A.; Jacobs, G.; Ji, Y.; Hamdeh, H.H.; Davis, B.H. Fischer-Tropsch synthesis: Characterization Rb promoted iron catalyst. Catal. Lett. 2008, 121, 1-11. [CrossRef]

22. Parkinson, G.S. Iron oxide surfaces. Surf. Sci. Rep. 2016, 71, 272-365. [CrossRef]

23. Li, J.; Cheng, X.; Zhang, C.; Chang, Q.; Wang, J.; Wang, X.; Lv, Z.; Dong, W.; Yang, Y.; Li, Y.W. Effect of alkalis on iron-based Fischer-Tropsch synthesis catalysts: Alkali-FeOX interaction, reduction, and catalytic performance. Appl. Catal. A Gen. 2016, 528, 131-141. [CrossRef]

24. Cheng, K.; Ordomsky, V.V.; Legras, B.; Virginie, M.; Paul, S.; Wang, Y.; Khodakov, A.Y. Sodium-promoted iron catalysts prepared on different supports for high temperature Fischer-Tropsch synthesis. Appl. Catal. A Gen. 2015, 502, 204-214. [CrossRef]

25. Xiong, H.; Motchelaho, M.A.; Moyo, M.; Jewell, L.L.; Coville, N.J. Effect of Group I alkali metal promoters on Fe/CNT catalysts in Fischer-Tropsch synthesis. Fuel 2015, 150, 687-696. [CrossRef]

26. Ngantsoue-Hoc, W.; Zhang, Y.; O’Brien, R.J.; Luo, M.; Davis, B.H. Fischer-Tropsch synthesis: Activity and selectivity for Group I alkali promoted iron-based catalysts. Appl. Catal. A Gen. 2002, 236, 77-89. [CrossRef]

27. Dry, M.E.; Oosthuizen, G.J. The correlation between catalyst surface basicity and hydrocarbon selectivity in the Fischer-Tropsch synthesis. J. Catal. 1968, 11, 18-24. [CrossRef]

28. Dry, M.E.; Shingles, T.; Boshoff, L.J.; Oosthuizen, G.J. Heats of chemisorption on promoted iron surfaces and the role of alkali in Fischer-Tropsch synthesis. J. Catal. 1969, 15, 190-199. [CrossRef]

29. Rajabi, Z.; Martinelli, M.; Watson, C.D.; Cronauer, D.C.; Kropf, A.J.; Jacobs, G. Influence of Cs Loading on Pt/m-ZrO2 Water-Gas Shift Catalysts. Catalysts 2021, 11, 570. [CrossRef]

30. Li, J.; Zhang, C.; Cheng, X.; Qing, M.; Xu, J.; Wu, B.; Yang, Y.; Li, Y. Effects of alkaline-earth metals on the structure, adsorption, and catalytic behavior of iron-based Fischer-Tropsch synthesis catalyst. Appl. Catal. A Gen. 2013, 464-465, 10-19. [CrossRef]

31. Luo, M.; Davis, B.H. Fischer-Tropsch synthesis: Group II alkali-earth metal promoted catalysts. Appl. Catal. A Gen. 2003, 246, 171-181. [CrossRef]

32. Yang, J.; Sun, Y.; Tang, Y.; Liu, Y.; Wang, H.; Tian, L.; Wang, H.; Zhang, Z.; Xiang, H.; Li, Y. Effect of magnesium promoter on iron-based catalyst for Fischer-Tropsch synthesis. J. Mol. Catal. A Chem. 2006, 245, 26-36. [CrossRef]

33. Li, J.; Hou, Y.; Song, Z.; Liu, C.; Dong, W.; Zhang, C.; Yang, Y.; Li, Y. Chemical and structural effects of strontium on iron-based Fischer-Tropsch synthesis catalysts. Mol. Catal. 2018, 449, 1-7. [CrossRef]

34. Tao, Z.; Yang, Y.; Zhang, C.; Li, T.; Wang, J.; Wan, H.; Xiang, H.; Li, Y. Effect of calcium promoter on a precipitated iron-manganese catalyst for Fischer-Tropsch synthesis. Catal. Commun. 2006, 7, 1061-1066. [CrossRef]

35. Pour A., N.; Housaindokht, M.R.; Tayyari, S.F.; Zarkesh, J.; Alaei, M.R. Kinetic studies of the Fischer-Tropsch synthesis over La, $\mathrm{Mg}$ and Ca promoted nano-structured iron catalyst. J. Nat. Gas Sci. Eng. 2010, 2, 61-68. [CrossRef]

36. Gallegos, N.G.; Alvarez, A.M.; Cagnoli, M.V.; Bengoa, J.F.; Marchetti, S.G.; Mercader, R.C.; Yeramian, A.A. Selectivity to Olefins of $\mathrm{Fe} / \mathrm{SiO} 2-\mathrm{MgO}$ Catalysts in the Fischer-Tropsch Reaction. J. Catal. 1996, 161, 132-142. [CrossRef]

37. Toby B., H.; Von Dreele R., B. GSAS-II: The genesis of a modern open-source all-purpose crystallography software package. J. Appl. Cryst. 2013, 46, 544-549. [CrossRef]

38. Liu, X.W.; Zhao, S.; Meng, Y.; Peng, Q.; Dearden, A.K.; Huo, C.F.; Yang, Y.; Li, Y.W.; Wen, X.D. Mossbauer Spectroscopy of Iron Carbides: From Prediction to Experimental Confirmation. Sci. Rep. 2016, 6, 26184. [CrossRef] [PubMed]

39. Paalanen, P.P.; van Vreeswijk, S.H.; Weckhuysen, B.M. Combined In Situ X-ray Powder Diffractometry/Raman Spectroscopy of Iron Carbide and Carbon Species Evolution in $\mathrm{Fe}(-\mathrm{Na}-\mathrm{S}) / \alpha-\mathrm{Al} 2 \mathrm{O} 3$ Catalysts during Fischer-Tropsch Synthesis. ACS Catal. 2020, 10, 9837-9855. [CrossRef]

40. Harris, J.; Andersson, S. H2 Dissociation at Metal Surfaces. Phys. Rev. Lett. 1985, 55, 1583. [CrossRef] [PubMed]

41. Xu, J.; Bartholomew, C.H. Temperature-programmed hydrogenation (TPH) and in situ Mossbauer spectroscopy studies of carbonaceous species on silica-supported iron Fischer-Tropsch catalysts. J. Phys. Chem. B 2005, 109, 2392-2403. [CrossRef] [PubMed] 
42. Pendyala, V.R.R.; Graham, U.M.; Jacobs, G.; Hamdeh, H.H.; Davis, B.H. Fischer-Tropsch Synthesis: Morphology, phase transformation and carbon-layer growth of iron-based catalysts. Chem CatChem 2014, 6, 1952-1960. [CrossRef]

43. Arakawa, H.; Bell, A.T. Effects of potassium promotion on the activity and selectivity of iron Fischer-Tropsch catalysts. Ind. Eng. Chem. Process Des. Dev. 1983, 22, 97-103. [CrossRef]

44. Raje, A.P.; O'Brien, R.J.; Davis, B.H. Effect of potassium promotion on iron-based catalysts for Fischer-Tropsch synthesis. J. Catal. 1998, 180, 36-43. [CrossRef]

45. Kummer, J.T.; Emmett, P.H. Fischer-Tropsch Synthesis Mechanism Studies. The Addition of Radioactive Alcohols to the Synthesis Gas. J. Am. Chem. Soc. 1953, 75, 5177-5183. [CrossRef]

46. Jacobs, G.; and Davis, B.H. Applications of Isotopic Tracers in Fischer-Tropsch Synthesis. Catal. Sci. Technol. 2014, 4, 3927-3944. [CrossRef]

47. Ma, W.; Jacobs, G.; Graham, U.M.; Davis, B.H. Fischer-Tropsch Synthesis: Effect of K Loading on the Water-Gas Shift Reaction and Liquid Hydrocarbon Formation Rate over Precipitated Iron Catalysts. Top. Catal. 2014, 57, 561-571. [CrossRef]

48. Housecroft, C.E.; Sharpe, A.G. Inorganic Chemistry, 2nd ed.; Pearson: Harlow, UK, 2005; pp. 880-882. 